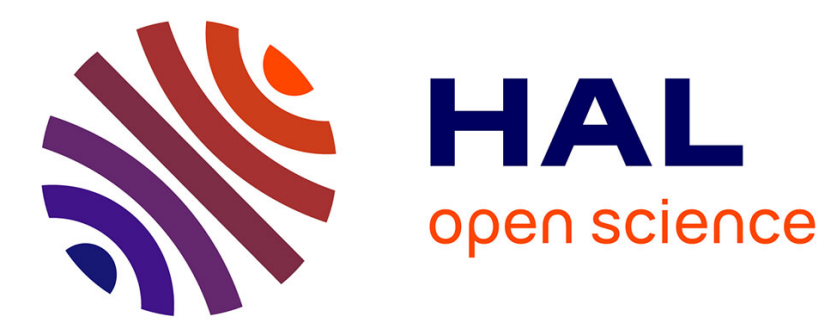

\title{
The Role of the Tutor in the Resilience of the Post-Bankruptcy Entrepreneur: The Case of the 60.000 Rebonds Association \\ Julien Cusin
}

\section{- To cite this version: \\ Julien Cusin. The Role of the Tutor in the Resilience of the Post-Bankruptcy Entrepreneur: The Case of the 60.000 Rebonds Association. Revue de l'Entrepreneuriat, 2017, 16 (2), pp.91-122. 10.3917/en- tre.162.0091 . hal-03239143}

\section{HAL Id: hal-03239143 \\ https://hal.science/hal-03239143}

Submitted on 27 May 2021

HAL is a multi-disciplinary open access archive for the deposit and dissemination of scientific research documents, whether they are published or not. The documents may come from teaching and research institutions in France or abroad, or from public or private research centers.
L'archive ouverte pluridisciplinaire HAL, est destinée au dépôt et à la diffusion de documents scientifiques de niveau recherche, publiés ou non, émanant des établissements d'enseignement et de recherche français ou étrangers, des laboratoires publics ou privés. 


\title{
THE ROLE OF THE TUTOR IN THE RESILIENCE OF THE POST- BANKRUPTCY ENTREPRENEUR: THE CASE OF THE 60.000 REBONDS ASSOCIATION
}

\author{
Julien CUSIN \\ Maître de Conférences \\ IAE de Bordeaux \\ erm/IRGO \\ 35, avenue Abadie \\ 33072 Bordeaux Cedex \\ Tél. : 0556009698 \\ julien.cusin@u-bordeaux.fr
}

\begin{abstract}
Entrepreneurs' post-failure recovery has previously been approached from the perspective of individual resilience. This recovery dynamic involves interactions between the entrepreneurs and their environment. Our paper studies the role of the tutor as an active external support in the entrepreneur's resilience process. We consider the case of an association that supports entrepreneurs who have filed for bankruptcy and show how the tutor regulates the entrepreneur's post-failure resilience process, involving other stakeholders to form a resilience system. We also show how the tutor must manage its image within this system in the interests of the recovering entrepreneurs.
\end{abstract}

Key words: entrepreneurial failure - bankruptcy - resilience - tutor - case study 


\section{THE ROLE OF THE TUTOR IN THE RESILIENCE OF THE POST-BANKRUPTCY ENTREPRENEUR: THE CASE OF THE 60.000 REBONDS ASSOCIATION}

\section{INTRODUCTION}

Failure is omnipresent and inevitable in the context of business venture creation (Cope, et al. 2004; Singh, Corner \& Pavlovich, 2015; Ucbasaran, Shepherd, Lockett \& Lyon, 2013; Wiklund, Baker \& Shepherd, 2010), regardless of the type of failure (e.g. discontinuity of ownership, discontinuity of the business, bankruptcy, etc.) (Ucbasaran, et al., 2013). Quite logically, the issue of the post-failure entrepreneurs' future has been the subject of many papers in the last dozen or so years (Cope, 2011; Shepherd, 2003; Ucbasaran, et al., 2013).

Among all the existing literature on the consequences of entrepreneurial failure (in the broad sense), Shepherd (2003, 2009), for instance, extended the work of Stroebe \& Schut (1999) and noted how failed entrepreneurs seesaw between two forms of 'coping' (loss orientation and restoration orientation), enabling them to speed up their recovery process. For his part, emphasizing the trauma of post-failure entrepreneurs, Cope (2011) observed three key stages in their recovery: psychological distancing from the failure, retro-analysis, and reflective action.

In positive psychology, this emotional and cognitive ability to recover in the face of adversity is called resilience (Bernard \& Barbosa, 2016; Bhamraa, Daniab \& Burnarda, 2011; Bullough, Renko \& Myatt, 2014; Byrne \& Shepherd, 2015; Fredrickson, 1998), even though the possibilities of articulation between grief recovery and resilience - in the context of an entrepreneurial failure - have not been fully explored in the literature on entrepreneurship to date. At all events, the concept of resilience is very common nowadays in the entrepreneurship literature (Ayala \& Manzano, 2014; Bernard \& Barbosa, 2016; Bullough, et al., 2014; Hayward, Foster, Sarasvathy \& Fredrickson, 2010; Manzano \& Ayala, 2013). Increasingly, resilience is presented by the authors not only as a personality trait, but also as a dynamic process involving interactions between the individual victim of a trauma - in our case, due to entrepreneurial failure (Cope, 2011) - and their social environment (Ayala \& Manzano, 2014; Bernard \& Barbosa, 2016; Cyrulnik, 2011).

However, we observed that studies on recovery from failure explore this issue uniquely from the perspective of failed entrepreneurs rather than that of the social environment, the exact role of which has never really been investigated in detail. This is all the more regrettable in that resilience is not a fixed attribute for the individual concerned but may, on the contrary, be stimulated and cultivated (Ayala \& Manzano, 2014; Brewer \& Hewstone, 2004; Bullough \& Renko, 2013). In other words, it is possible that appropriate external support will promote the entrepreneur's post-failure recovery. Our study therefore focuses on recovering entrepreneurs through the lens of the resilience tutor (Cyrulnik, 2011), which is defined here as an individual or a collective reference from the post-failure entrepreneur's social environment, liable to act in such a way as to help them to spring back, especially in career terms. Thus, we investigate the role of the tutor as an active external support in the resilience process of failed entrepreneurs, together with the conditions for successful interaction between the latter and the tutor.

To this end, we study the case of a collective tutor of resilience, namely, a French non profit-making association, 60.000 Rebonds ${ }^{1}$, which, since 2012, has supported many entrepreneurs who have gone bankrupt. We chose this approach since the literature on resilience to date has tended to focus on conceptual reflections (Ayala \& Manzano, 2014; Bhamraa, et al., 2011; Sutcliffe \& Vogus, 2003) and lacks qualitative empirical data on the processes and mechanisms that underpin an individual's resilience (Davidson, 2009). In short, we show, first, how the tutor regulates the entrepreneur's post-bankruptcy resilience process (managing the switch between retro-analysis and new entrepreneurial plans, discarding the tutor/entrepreneur hierarchy and replacing it with a 'gifts and return gifts' logic, positioning the expected degree of contradiction in discussions, and providing flexible adaptation of the processes). We then

\footnotetext{
${ }^{1}$ http://60000rebonds.com/
} 
illustrate how, in creating a context favourable to the entrepreneur's post-bankruptcy resilience, the tutor needs to go beyond the simple dyadic tutor/entrepreneur relationship, involving other stakeholders in the recovery dynamic. We thus identify a system of resilience within the social environment. To be of indirect use to recovering entrepreneurs, the tutor must therefore manage its image with the different partners (e.g. financiers) very carefully.

\section{REVIEW OF THE LITERATURE}

In this section, we articulate both post-failure and resilience processes through a synthetic figure (cf. Figure 1).

\subsection{THE ENTREPRENEUR'S POST-FAILURE PROCESS}

Ucbasaran, et al. (2013) examined current knowledge of the trajectory of entrepreneurs following failure. Based on the work by Cope (2011), they identify a fairly long, three-stage process (cf. Table 1).

Table 1: Life after failure for an entrepreneur (based on Ucbasaran, et al., 2013: 174)

\begin{tabular}{|c|c|}
\hline \multirow[b]{2}{*}{$\begin{array}{l}\text { Short term } \\
\text { The entrepreneur is faced with the immediate } \\
\text { impact of the failure }\end{array}$} & The 'aftermath' (i.e. costs of business) \\
\hline & $\begin{array}{l}\text { - Financial } \\
\text { - Social } \\
\text { - Psychological } \\
\text { - Inter-relational }\end{array}$ \\
\hline \multirow{2}{*}{$\begin{array}{l}\text { The entrepreneur makes sense of the failure and } \\
\text { draws lessons from it }\end{array}$} & $\begin{array}{l}\text { The social-psychological process of business } \\
\text { failure }\end{array}$ \\
\hline & $\begin{array}{l}\text { - Learning } \\
\text { - Sensemaking }\end{array}$ \\
\hline \multirow[b]{2}{*}{$\begin{array}{l}\text { Long term } \\
\begin{array}{l}\text { The entrepreneur recovers from the failure and re- } \\
\text { emerges professionally }\end{array}\end{array}$} & Outcomes \\
\hline & $\begin{array}{l}\text { - Recovery } \\
\text { - Cognitive outcomes } \\
\text { - Behavioural outcomes }\end{array}$ \\
\hline
\end{tabular}

We now turn to each of these three stages in more detail:

1- The 'Aftermath' (i.e. business costs): Failures are major blows for entrepreneurs (Cope, 2011; Snell, 1992). On this issue, the literature on entrepreneurship does not hesitate to use the term 'trauma', borrowed from psychology ${ }^{1}$ (Cardon, Stevens \& Potter, 2011; Cope, 2011; Jenkins, Wiklund \& Brundin, 2014; Shepherd, 2009; Singh, et al., 2015; Ucbasaran, Westhead, Wright \& Flores, 2010; Ucbasaran, et al., 2013). A psychologist such as Josse (2014) also emphasizes that major events in the organizational life - as failures undoubtedly are - can cause a trauma. Cope (2011) notes, for instance, the existence of three closely linked traumas. First, in financial terms, entrepreneurs will experience a fall in income. If they acted as the guarantors of their business, they may also be faced with personal debts that could take years to pay off (Bacq, et al., 2009 ; Cope, 2011; De Hoe \& Janssen, 2014 ; Ucbasaran, et al., 2013). In addition, in social terms, many entrepreneurs who have experienced failure tend to divorce and/or cut off ties with their friends and family (Cope, 2011; Singh, Corner \& Pavlovich, 2007; Singh, et al., 2015; Ucbasaran, et al., 2013). Similarly, they may be professionally stigmatized (Sutton \& Callahan, 1987). For cultural reasons, this is more frequent in Europe than in the United States (Bacq, et al., 2009 ; Cope, 2011; De Hoe \& Janssen, 2014 ; Singh, et al., 2015). Together with the splintering of their network of contacts (Harris \& Sutton, 1986; Ucbasaran, et al., 2013; Singh, et al., 2015), entrepreneurs may find it difficult to get a 'second chance' (Bacq, et al., 2009 ; De Hoe

\footnotetext{
${ }^{1}$ Freud (1920) defines trauma as follows: 'All external stimuli strong enough to break into the psychic life of the subject.' The trauma is therefore an important emotional shock, so that the individual then has a feeling of rupture (Josse, 2014).
} 
\& Janssen, 2014 ; Singh, et al., 2015). Thus, it is often difficult for them to find a paid job or the financial/human resources required to start a new business (Bacq, et al., 2009 ; Cardon, et al., 2011; Cope, 2011; De Hoe \& Janssen, 2014 ; Shepherd \& Haynie, 2011; Singh, et al., 2015; Sutton \& Callahan, 1987; Ucbasaran, et al., 2013). Finally, in psychological terms, we should not forget the very strong ties between entrepreneurs and their business: 'Entrepreneurs often describe their businesses as their 'babies', expressing personal connection and even identification with their businesses' (Cardon, Zietsma, Saparito, Matherne \& Davis, 2005: 23). Entrepreneurs are enthusiasts who identify closely with their business venture and are emotionally involved in it (Cardon, et al., 2005; Shepherd, 2009), making failure a particularly devastating event for them (Cope, 2011; Shepherd, 2003; Ucbasaran, et al., 2013; Singh, et al., 2015). Ucbasaran, et al. (2013) point to the parallel with grief, as in the loss of a loved one, which is almost systematically found in the literature in this context (Cardon \& McGrath, 1999; Cope, 2011; Harris \& Sutton, 1986; Shepherd, 2003; Shepherd, 2009; Shepherd, Covin \& Kuratko, 2009; Shepherd, Wiklund \& Haynie, 2009; Singh, et al., 2007) ${ }^{1}$. Moreover, Shepherd (2003) points to the psychology literature on grief after the death of a loved one (Stroebe \& Schut, 1999) and suggests transferring it to the context of a business failure, at the same time, identifying two recovery processes. To simplify, we may consider that the first (loss orientation) consists of looking back, while the second (restoration orientation) involves moving forward:

- The loss-oriented approach means that the entrepreneur confronts and works on the past failure in order to develop a more positive view of the experience. The aim is to ensure that in the future, the failure is no longer felt as a trauma. Shepherd (2003: 322) notes the importance of discussing it with others: 'Self-employed individuals with a loss orientation might seek out friends, family, or psychologists to talk about their grief.' However, such studies on the emotional dimension of failure generally focus on the entrepreneur's grief, without necessarily extending reflections to the role that the social environment can play in the recovery process.

- The restoration-oriented approach is based on a certain degree of proactiveness by the entrepreneur (immediate search for a job, rapid creation of a new business, etc.) to counter their inactivity and their financial problems (a secondary sources of stress linked to failure), and to distance themselves from the failure as such, in other words, the primary source of stress. In this case, entrepreneurs display a form of avoidance with regard to the experience that they prefer not to dwell on (the failure is pushed to one side).

In practice, Shepherd (2003) suggests that recovering is not simply a choice between one or other of these dynamics, but that the entrepreneur is more likely to oscillate between the two ways of 'coping', thereby speeding up the recovery process (echoing the 'dual process model of coping with bereavement' of Stroebe \& Schut (1999: 197), the author speaks about 'a dual process of grief recovery', p. 323).

2- The social psychological processes of business failure: as Ucbasaran, et al. (2013) point out, there is an extensive body of literature on learning through failure in the field of entrepreneurship (e.g. Byrne \& Shepherd, 2015 ; Cope, 2011; McGrath, 1999; Shepherd, 2003), where failure is seen as an opportunity for entrepreneurs to take a critical look at themselves and the way to effectively manage a business (Cope, 2011; Shepherd, 2003; Ucbasaran, et al., 2013). Ucbasaran, et al. (2013: 183) explain that 'failure represents a 'clear signal' that something went wrong and motivates individuals to allocate attention to understand what that something was.' For the authors, making sense of failure is likely to incite entrepreneurs to alter their mental models. Conducting a critical self-reflection (Cope, 2011) implies however 1) that entrepreneurs are not victims of a self-complacency bias, systematically putting their unhappy experience down

\footnotetext{
${ }^{1}$ The conceptual transfer of 'grief' in management science has been questioned both at epistemological and theoretical levels, but it is beyond the scope of this article to review this specific point (for further consideration, see Pailot, 2014). Anyway, since in this paragraph we are relying on multiple articles published in excellent international journals (in the field of management science) - such as Academy of Management Journal, Academy of Management Review or Journal of Business Venturing - we consider this conceptual transfer as scientifically acceptable.
} 
to external causes so as to spare themselves (Miller \& Ross, 1975), and 2) that they have taken their failure on board in emotional terms (Shepherd, 2003), something that generally requires time. It would indeed appear that negative emotions can hamper the capacity to learn from an event (Isen \& Baron, 1991; Shepherd, 2003), especially when the circumstances surrounding the event are ambiguous (Kumar, 1997; Shepherd, 2003). For example, Shepherd (2003) notes that entrepreneurs who are still psychologically affected by a failure are less likely to give themselves the time to consider the factors relative to this setback. When there is indeed learning, the entrepreneur needs to use the lessons drawn from the failure to start a new business if the new knowledge is not to be wasted (Cope, 2011; Shepherd, 2003; Singh, et al., 2015; Ucbasaran, et al., 2010).

3- Outcomes: for Ucbasaran, et al. (2013), we can judge whether or not an individual has recovered from the failure by observing the long-term cognitive and behavioural impact of the bankruptcy on the entrepreneur (optimism, confidence, self-esteem, self-efficacy, propensity to take risks, etc.) during the re-emergence stage (Cope, 2011). On this point, Shepherd (2003) suggests that individuals have overcome their grief linked to failure when thinking about the event no longer generates negative emotional feelings. Cope (2011: 615) adds that this would be the case when the entrepreneur has 1) stepped back from the failure in psychological terms (initial hiatus), 2) begun a determined and conscious critical examination to make sense of the failure (critical reflection) and 3) begun thinking about overcoming the failure and grasping new opportunities (reflective action). The author considers these three elements to be closely linked. First, the hiatus helps entrepreneurs to clear their thoughts and restore energy, which in turn fosters a critical analysis of the failure. Reflective action is also made possible by the initial recovery and the effort of critical thinking. Finally, critical reflection and reflective action contribute to the recovery process by helping entrepreneurs to close a painful chapter in their life. While these different stages appear to promote the entrepreneur's post-failure recovery, the literature says little about how each of the stages takes place in practice. How is the psychological shock of the failure absorbed by entrepreneurs? How do the latter develop a form of critical reflection? How do they begin their reflective action?

Ultimately, we can point out that the branch of research mentioned in this section - i.e. work about entrepreneurial grief (e.g. Shepherd, 2003, 2009) - studies reactions to entrepreneurial failure by using the concept of 'coping', which is close to the notion of resilience, without explicitly dealing with this idea (Bernard \& Barbosa, 2016). As summarized by Byrne \& Shepherd (2015: 396), 'in positive psychology, recovery from negative experiences is explained in terms of psychological resilience - namely, the ability to "bounce back" from adversity (Fredrickson, 1998).' In other words, the concept of resilience is viewed, in the literature on entrepreneurship, as a form of emotional and cognitive ability that is useful for the entrepreneur to bounce back after failures (Bernard \& Barbosa, 2016). An author like Hanus (2009) certainly raises the question of the considerable differences between grief and resilience, but also highlights the common points (e.g. traumatic origin, long-term processes, battle of conflicting emotions and feelings, etc.), analogies and possibilities of "articulation" (p.21) between these two concepts. By adopting this perspective, we seek to deepen this idea. Indeed, to date, there has been a theoretical gap on that issue in the literature on entrepreneurship.

\subsection{THE ENTREPRENEUR'S RESILIENCE IN INTERACTION WITH THE ENVIRONMENT}

\subsubsection{Making the entrepreneur's post-failure resilience process operational}

In psychology, the ability to bounce back following hardship is called resilience (Bhamraa, et al., 2011; Bullough, et al., 2014). This concept is closely linked to the property of an element to return to its original form following a shock (Bhamraa, et al., 2011), or even to go beyond this simple state of equilibrium (Luthar, Ciccheti \& Becker, 2000). More specifically, resilience is usually considered to be an ability 'to face up, integrate and to be transformed by adverse experiences or negative events, without major behavioural or psychic disturbances and 
while maintaining a quality of life. It corresponds to a dynamic and evolving process, which includes an adaptive approach and the maintenance of psychic integrity despite exposure to pathogenic contexts.' (Arnaut, 2015: 11). In other words, resilience refers to the human capacity to overcome severe trauma (Ayala \& Manzano, 2014; Bonanno, 2004; Connor \& Davidson, 2003; Newman, 2005), given that entrepreneurial failure has been defined above as a traumatic event. Finally, in the concept of resilience, there is the idea of a positive adaptation of the individual concerned (Bernard \& Barbosa, 2016).

Bhamraa, et al. (2011), however, observe that there have been few empirical studies on the concept of resilience (Sutcliffe \& Vogus, 2003) as the literature on the subject is mainly conceptual. This is largely due to the fact that it is very difficult to develop an operational definition of resilience (Ayala \& Manzano, 2014; Bernard \& Barbosa, 2016; Josse, 2014; Mohaupt, 2009). Ayala \& Manzano (2014) point out that Connor \& Davidson (2003) proposed a resilience measurement scale that has been validated in various studies (Burns \& Anstey, 2010; Karairmak, 2010; Lamond, et al., 2008). Adopting this measurement scale, Manzano \& Ayala (2013) identified three distinct factors in the entrepreneur's resilience:

1- Hardiness. Entrepreneurs retain their self-control when confronted with unfavourable situations and demonstrate courage, tenacity and daring.

2- Resourcefulness. Entrepreneurs have resources, capacities and expertise that enable them to manage the unfavourable situations they have to face.

3- Optimism. Entrepreneurs are able to maintain a positive attitude in situations of adversity. They consider their mistakes as learning opportunities, for instance.

More generally, the concept of resilience is now widely used in the field of entrepreneurship (Ayala \& Manzano, 2014; Bernard \& Barbosa, 2016; Bullough \& Renko, 2013; Bullough, et al., 2013), even though this conceptual transfer certainly raises as many epistemological and theoretical questions as the issue of grief (Pailot, 2014). Resilience is generally considered to be an important quality for entrepreneurs (Ayala \& Manzano, 2014; Sutcliffe \& Vogus, 2003). Firstly, resilient entrepreneurs are not afraid of failure. When they come up against it, they show a certain degree of psychological resistance (Baron \& Markman, 2000; Bullough, et al., 2014; Markman, Baron \& Balkin, 2005). In effect, they have a high level of selfesteem and consider themselves to be in control of events. Moreover, resilient entrepreneurs are able to learn from their mistakes and develop their expertise by drawing lessons from failure, demonstrating a significant capacity for adaptation and renewal over time (Ayala \& Manzano, 2014). Making sense of the situations they experience (Antonovsky, 1998) helps them to acquire the knowledge, capacities and skills they need to face the future with a positive attitude, creativity and optimism (Ayala \& Manzano, 2014). Thus, in the case of failure, resilient entrepreneurs will feel more confident and will be ready to launch a new business venture if new opportunities arise (Bullough, et al., 2014). Ayala \& Manzano (2014: 127) argue that 'resilient entrepreneurs [...] are not afraid to fail. If this happens, despite adversity, they 'rise again' stronger than before because they have learnt from the situation.' This very individualistic reading of resilience - as if entrepreneurs were some kind of heroic figures - may seem surprising, because it totally neglects their social-emotional resources.

Anyway, the authors empirically argue that resilience may be considered a key factor in business success. Entrepreneurs' resilience appears to be based on three crucial and closely interwoven factors, demonstrated through the entrepreneur's ability to: 1) absorb the emotional shock caused by the failure, 2) develop a true intelligence of failure, and 3) launch a new business venture following their initial failure. This reading helps make the notion of resilience operational, at the same time reflecting the models of Cope (2011) and Ucbasaran, et al. (2013) (cf. Figure 1). In short, we speak about resilience when entrepreneurs who have experienced an emotionally devastating failure can finally re-emerge and plan for the future through the launch of a new business, without remaining fixated on their trauma. Thanks to their ability to draw lessons from the failure, they emerge from it strengthened by the experience (improved technical and managerial skills, better management of adverse events, clearer view of business opportunities, etc.). 


\subsubsection{The importance of entrepreneur/environment interaction in resilience}

In the literature, individual resilience is increasingly presented as a dynamic process (and not only as a personality trait) which develops over time and involves both internal resources such as resourcefulness, self-efficacy and the locus of control (Du Plessis \& Van Breda, 2001) and interaction between the individual and his/her environment (Bernard \& Barbosa, 2016; Egeland, Carlson \& Sroufe, 1993). According to Ayala \& Manzano (2014: 127), 'resilience is the capacity an entrepreneur has to overcome particularly difficult circumstances. This capacity for adaptation and "bouncing back" in the face of adversity depends on the individual's resources and their interaction with the environment.' In the entrepreneurship literature, the approach to resilience focused on interactions with the environment, which acts as a support for the dynamic of the resilience, has been little studied (Bernard \& Barbosa, 2016). And yet, while resilience is specific to an individual, it should not be considered as a fixed personality trait or an innate attribute (Bullough \& Renko, 2013) but may indeed be developed, encouraged and strengthened (Ayala \& Manzano, 2014; Brewer \& Hewstone, 2004; Bullough \& Renko, 2013). In other words, resilience is not something rare and extraordinary but, on the contrary, may be learnt over time and from experience (Bullough, et al., 2014; Coutu, 2002). Bonanno (2004) suggests that resilience is far more commonplace than is often thought. There are several ways to develop resilience, some of which are relatively unexpected.

Individuals are therefore not resilient on their own, but in a socio-emotional context. Their familial and extra-familial supports reinforce or compensate their internal resources and modes of defence (Arnaut, 2015). For instance, many studies have underscored the role of education in helping students (future entrepreneurs) to learn from their mistakes (Ayala \& Manzano, 2014; Shepherd, 2004). Similarly, among other exogenous factors liable to have a positive impact on entrepreneurs' resilience, Bullough \& Renko (2013) include listening to accounts of other entrepreneurs who have managed to overcome their difficult periods ('peer-to-peer coaching'). Their feedback not only provides a powerful motivator, but also helps them to indirectly learn from their experience in the face of adversity. 'In order to build [...] resilience, entrepreneurs [...] need to [...] seek out [...] mentoring opportunities to learn by modelling others who have been resilient through challenging times,' Bullough \& Renko (2013: 343) argue. The authors thus highlight the positive role of tutors who provide an objective and critical view, as well as encouragement for failed entrepreneurs.

For people in difficult situations, appropriate external support may provide an opportunity to re-establish self-confidence, to become more aware of their personal strengths and weaknesses and to think about new professional opportunities (London, 1996). In this context, Cyrulnik (2011) noted that individuals who have been victims of trauma should develop new ties with people from their social environment to give them emotional sustenance. It has indeed been shown that after a tragedy, positive emotions (e.g. giving hope or courage) protect individuals from depression and can help to foster their future happiness (Bullough \& Renko, 2013; Bullough, et al., 2014; Fredrickson, Tugade, Waugh \& Larkin, 2003). Thus, if individuals can develop a relationship of trust with external tutors, the latter will not only help the former to escape from their isolation, but will also help them to begin the recovery process (Cyrulnik, 2011). Indeed, tutors are able to understand the hidden suffering. They also show that they understand and respect this suffering without indiscretion. Finally, they help the traumatized individuals mostly by showing them how much they trust in them, in their ability and in their future (Hanus, 2009).

There is little in the literature on this idea that a tutor (individual or collective) can help to promote post-failure entrepreneurial resilience. In effect, while the concept of resilience has featured prominently in recent studies on entrepreneurship, the authors concerned have always adopted the perspective of the person who failed (Bullough, et al., 2014; Cope, 2011; Hayward, et al., 2010). This may seem surprising given that the resilience process is presented, as we said earlier, through a concept of interaction between the entrepreneur and his or her environment. For example, when Ayala \& Manzano (2014) suggest that a resilient entrepreneur is able to develop 
and mobilise resources that often they had no idea they possessed, we might ask to what extent the entrepreneur benefits from outside support to achieve this. We therefore investigate how the tutor helps bring out latent unsuspected resources (Hanus, 2009) for the post-failure entrepreneur. Thus, our study is original in its perspective, since it adopts the lens of the entity within the social environment that provides support to help entrepreneurs get back on their feet following a failure. More precisely, we explore the role played by the tutor in the entrepreneur's resilience process as an external active support within the social environment (cf. Figure 1), as well as the conditions for successful interaction between entrepreneurs and their tutor.

It should nevertheless be noted here that in this article we focus on a particular type of failure. Indeed, it appears that the concept of 'entrepreneurial failure' or 'business failure' is very different from one article to another, and that no definition is unanimous (Cope, Cave \& Eccles, 2004; De Hoe \& Janssen, 2014; Khelil, Smida \& Zouaoui, 2012; Ucbasaran, et al., 2013). As summarized by Ucbasaran, et al. (2013: 166), 'definitions (...) vary in terms of their inclusivity ranging from broad (discontinuity of ownership) to less permissive (discontinuity of the business) to narrow (bankruptcy) definitions.' This latter approach is the most widespread in the literature, although bankruptcies account for only $15 \%$ of company disappearances (Zacharakis, Meyer \& Decastro, 1999; De Hoe \& Janssen, 2014). To give a more precise idea of the scale of the problem, France beat its record of bankruptcies in 2013, with a total of 63,452 business failures (Le Figaro, $12 / 02 / 2014)$. In this specific case, the company is unable to meet its financial commitments when they fall due. This state of economic non-performance can, in some cases, lead to legal bankruptcy of the company. Thus, the termination of entrepreneurial activity is clearly involuntary (Bacq, Giacomin \& Janssen, 2009). This is precisely the perspective we have chosen in this research, because bankruptcy has the advantage of being based on 'an observable, recorded event' (Ucbasaran, et al., 2013: 174), making the entrepreneur's potential post-failure recovery simpler to identify and to understand from an empirical perspective. 


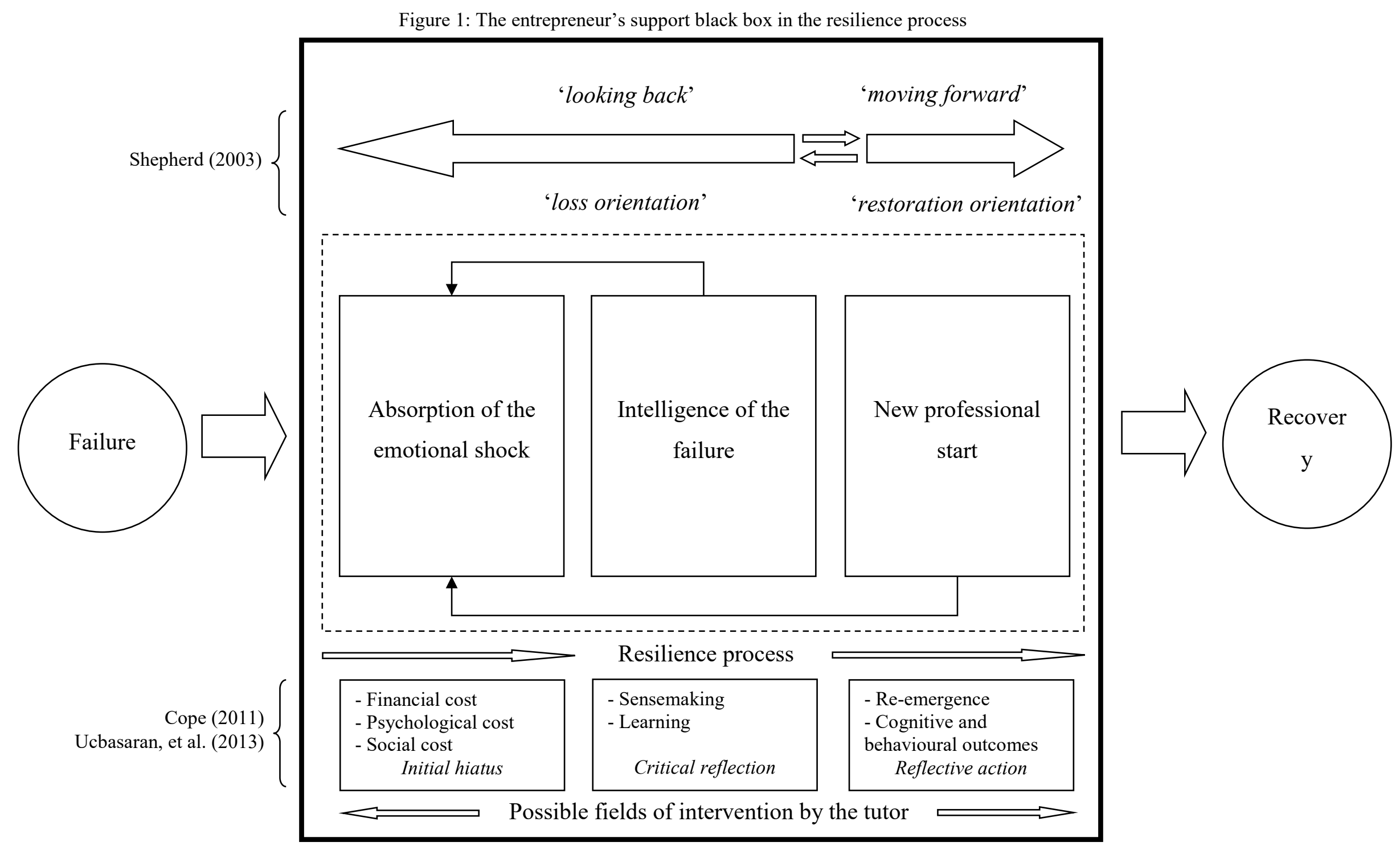


Although our research question focuses on the tutor of resilience, it combines different levels of analysis since qualitative research is more likely to apprehend such complex processes in all of their richness (Graebner, Martin \& Roundy, 2012).

\section{METHODOLOGY}

To explore our research question, we conducted an in-depth case study with the 60.000 Rebonds association in France. For Yin (1990), selecting just one case study is pertinent when the latter helps to provide an academic understanding of a relatively unknown phenomenon through an in-depth analysis, in our case with regard to the role of a tutor in resilience. Our approach also answers Blackburn and Kovalainen's (2009) call for more qualitative studies in entrepreneurship research on business closures. Lastly, our approach also takes into account the views of Davidson (2009), who hoped for more qualitative empirical data on the processes and mechanisms that underpin resilience in individuals.

\subsection{CHOICE OF FIELD OF STUDY}

We studied the case of a non-profit making association - 60.000 Rebonds [60,000 recoveries] - that provides personal, professional and financial support to business men and women who have filed for bankruptcy. The story of its founder is important in order to fully understand the context of the association.

After 25 years as a top manager at Danone, Philippe Rambaud created a consulting company in 2000 which filed for bankruptcy eight years later. 'I went through the triple trauma: personal, professional and financial,' he explained [conference/press - founder]. ${ }^{1}$ In parallel with setting up a new consulting venture, he decided to share his unfortunate experience with the 60,000 entrepreneurs that annually file for bankruptcy in France. In 2012, Philippe Rambaud launched the 60.000 Rebonds association in Bordeaux. At this time, three other similar associations already existed (Re-Créer, Second Souffle and SOS Entrepreneurs, respectively launched in 1999, 2010 and 2011), but the 60.000 Rebounds association was original in that it proposed a formalized and structured long-run support process, echoing our vision of the concept of resilience. Indeed, the recovering entrepreneurs (known as EER) are supported for two years, principally to help them develop a new entrepreneurial idea. ${ }^{2}$

Two years after its creation, the association had groups in ten French towns, with 250 volunteers and 150 post-bankruptcy entrepreneurs (i.e. whose company had gone bankrupt or into liquidation within 24 months of the date recorded by the Trade Tribunal). In Bordeaux, for example, there were 57 members in 2014 (16 post-bankruptcy entrepreneurs, 6 coaches, 13 mentors and 22 business experts). Initially, the association had three constitutive partners: the City of Bordeaux (2,000 euros/year for the association as a whole), Crédit Agricole Aquitaine bank (1,500 euros/year) and EY Bordeaux (10,000 euros/year). The association can also count on membership dues (100 euros/year). Despite the support of the Mulliez family since $2016^{3}$, the financial resources of the association are thus quite limited. Therefore, its support activities are based on volunteer work. The association also occasionally employs trainees (e.g. for the development of the website). For example, in 2014, expenses were only related to travel, accommodation, office supplies, computers and receptions. Nevertheless, there are occasionally donations (e.g. Fondation Entreprise Solidarité, BPI Group, etc.) to support new entrepreneurial initiatives.

\footnotetext{
${ }^{1}$ We systematically include the source of the quotes in italics between brackets.

${ }^{2}$ This is obviously a restrictive definition of resilience as entrepreneurs may recover in alternative ways (e.g. employment).

${ }^{3}$ The Mulliez family owns a large number of French retailers (e.g. Auchan, Boulanger, Cultura, Decathlon, Kiabi, Leroy Merlin, Norauto, etc.) and is considered by the media as a real 'empire'. Gérard Mulliez (founder of Auchan) is, as such, one of the wealthiest people in France.
} 
It may be noted here that the name of the association explicitly reflects our conceptual framework in that we have defined resilience as the capacity of an individual to recover from an adverse situation (Bhamraa, et al., 2011; Bullough, et al., 2014). In other words, the association was mainly created to help post-bankruptcy entrepreneurs to recover. The form of resilience studied here is thus deliberate and proactive (versus a more spontaneous form of resilience). In this perspective, the role of the association may be likened to that of a tutor of resilience (understood here in its collective sense).

In this respect, it is important to highlight that our main unit of analysis in this article is not the post-bankruptcy entrepreneur, but the association. We thus aim to find out to what extent the association can potentially be involved in a dynamic post-bankruptcy process of resilience, through its tools and actions. Therefore, the contingency of responses from entrepreneurs depending on variables related to the event and its characteristics (e.g. unpredictability, lack of anticipation, etc.) or to the entrepreneur (e.g. previous professional failures, physical and mental state at the time of failure, psychological readiness, coping strategies, etc.) - will not be considered here. We can nevertheless emphasize that all post-bankruptcy entrepreneurs studied have in common the fact of having turned to the association, because they were unable to bounce back by themselves and therefore sought external support. Such similarity in the experiences of post-bankruptcy entrepreneurs therefore makes relevant the use of a concept such as resilience.

\subsection{DATA COLLECTION AND ANALYSIS}

The data collected (April 2013 - April 2015) was extremely varied (cf. Table 2 and Appendix).

Table 2: Data collected

\begin{tabular}{|l|l|}
\hline Type of data & Quantification \\
\hline Individual and group interviews & 15 \\
\hline Field observations & 3 \\
\hline Conferences & 4 \\
\hline Press articles & 32 \\
\hline TV documentary & 1 \\
\hline Personal accounts (written and video) & 4 \\
\hline Miscellaneous documents & 14 \\
\hline
\end{tabular}

This corresponds to a total corpus of 547 pages of raw data on Word. To analyse the latter, we followed the template suggested by Gioia, Corley \& Hamilton (2013), which is increasingly used in management science (Monin \& Rüling, 2013). In particular, this is a standard methodology for understanding entrepreneurship in context (McKeever, Jack \& Anderson, 2015). 'In this approach, researchers show their analytic work through a boxes and arrows figure that identifies data extracts grouped together according to first-order codes that are then grouped into secondorder themes at a higher level of abstraction' (Reay, 2014: 99). Table 2 summarizes the results of the empirical study and shows particularly how we progressed from 59 first-order codes to 8 second-order themes, and from 8 second-order themes to 3 aggregate second-order dimensions. ${ }^{1}$

The first-order coding is inductive, to the extent that its purpose is to reproduce faithfully the discourse of respondents. In other words, during this first step, we relied only on the transcriptions of interviews, ignoring the literature. Whenever we detected a new idea, we generated a new item. ${ }^{2}$ In a second step, the second-order coding consists in aggregating these items through two successive levels of abstraction, moving back and forth between the raw data

\footnotetext{
${ }^{1}$ In the 'findings' section, we provide many examples of quotes that enabled us to define these categories and themes.

2 An item is a short and simple sentence faithfully summarizing a verbatim record (each word of this synthetic item was really used by the respondent during the interview).
} 
and the literature (Mathias, Williams \& Smith, 2015), in an abductive approach. Thus, three second-order themes (shock absorption, intelligence of failure and new professional start) emerged from our conceptual framework, whilst the last five themes (flexibility of tools and processes, equal relations, gifts and return gifts, impression management and the resilience system) emerged from the field. Ultimately, according to the Gioia methodology, these secondorder themes and aggregate dimensions that emerged from our coding (cf. Table 2) are assembled in the grounded model of our study (cf. Figure 2 at the end of the 'findings' section). 
Table 2: Data structure following the methodology of Gioia, et al. (2013)

\begin{tabular}{|c|c|c|c|}
\hline 1st order codes & 2nd order themes & aggregate dimensions & \\
\hline $\begin{array}{l}\text { - The association assesses the psychological mindset of the EER } \\
\text { - The association helps the EER to overcome their failure } \\
\text { - The association helps to rebuild the EER's personal confidence (e.g. trust, self-esteem...) } \\
\text { - The association puts the EER in touch with external qualified experts (e.g. psychologist) } \\
\text { - The association takes the EER under the community wing so they are less isolated } \\
\text { - The association helps the EER with financial matters } \\
\text { - The association helps the EER to find a temporary job to give them financial stability } \\
\text { - The association helps the EER to manage social emergencies } \\
\text { - The association works to change society's image of entrepreneurial failure }\end{array}$ & Shock absorption & \multirow{3}{*}{$\begin{array}{l}\text { Action of the association with } \\
\text { respect to the resilience process } \\
\text { of entrepreneurs }\end{array}$} & \\
\hline $\begin{array}{l}\text { - The association helps the EER to view the failure from a positive angle } \\
\text { - The association helps the EER to draw lessons from their failure } \\
\text { - The association helps the EER to accept their share of responsibility for the failure } \\
\text { - The association helps the EER to step back and look objectively at how they operate } \\
\text { - The association helps the EER to recognise the repetition of certain errors } \\
\text { - The association helps the EER to identify anything that could impede their learning process }\end{array}$ & Intelligence of failure & & \\
\hline $\begin{array}{l}\text { - The association works with the EER on their new project } \\
\text { - Experts critically examine the EER's project with more or less enthusiasm } \\
\text { - A mentor helps the EER to develop their new project } \\
\text { - The association provides tools and skills to help the EER to develop their new project } \\
\text { - The association stops the EER from leaping headlong into a 'patch-up project' } \\
\text { - The association keeps its distance with respect to any decisions EER make about their project }\end{array}$ & New professional start & & \\
\hline $\begin{array}{l}\text { - The diverse profiles of EER mean that flexible processes are required } \\
\text { - The volunteers do not know all the association rules } \\
\text { - The volunteers retain a certain degree of room for manoeuvre in terms of the support they provide }\end{array}$ & $\begin{array}{l}\text { Flexible tools and } \\
\text { processes }\end{array}$ & \multirow{3}{*}{$\begin{array}{l}\text { Nature of relations between the } \\
\text { association and the entrepreneurs }\end{array}$} & \\
\hline $\begin{array}{l}\text { - The association rejects any kind of hierarchy between the EER and the experts } \\
\text { - The association works to develop a family/community spirit } \\
\text { - Trusting relationships are very important in the association, particularly between EER and volunteers } \\
\text { - The founder's failure is a story that is widely shared within the association, particularly between EER } \\
\text { - The volunteers speak openly about their failures with the EER } \\
\text { - As the mentors and experts also experienced failure, there is a natural empathy with the EER } \\
\text { - Hearing stories about other failures encourages EER to speak about their own story } \\
\text { - Hearing stories about post-bankruptcy recovery gives the EER hope }\end{array}$ & Equal relations & & \\
\hline $\begin{array}{l}\text { - Having a role of expert when you are an EER means that you feel less alone } \\
\text { - Having a role of expert when you are an EER helps to relativize your own failure } \\
\text { - Having a role of expert when you are an EER helps you to think through your own case } \\
\text { - Having a role of expert when you are an EER helps you to regain your pride } \\
\text { - EER show their gratitude by taking part in the association's communication events }\end{array}$ & Gifts and return gifts & & \\
\hline
\end{tabular}




\begin{tabular}{|c|c|c|c|}
\hline $\begin{array}{l}\text { - The association is very young and still needs to prove itself } \\
\text { - The association's image is closely linked to that of its figurehead } \\
\text { - The continual development and improvement of the processes helps give the association credibility } \\
\text { - The EER convey a positive image of the association } \\
\text { - The association seeks external support (e.g. leaders, media...) to convey a positive image } \\
\text { - The behaviours of some EER may harm the association in the eyes of its partners } \\
\text { - The association seeks to show its dynamism in order to raise money } \\
\text { - The positive image of the association has a knock-on effect on the EER } \\
\text { - The association paints a positive picture of its activities in its external communication } \\
\text { - The association avoids certain words considered as taboo (e.g. psychological) in its public discourse } \\
\text { - The association distances itself from the success/failure of recovering entrepreneurs } \\
\text { - The association fears that if EER do not recover, it will backfire on them }\end{array}$ & Impression management & \multirow{2}{*}{$\begin{array}{l}\text { Nature of relations between the } \\
\text { association and the external } \\
\text { stakeholders }\end{array}$} & \multirow{2}{*}{$\begin{array}{l}\overline{0} \\
\frac{0}{0} \\
\stackrel{0}{0} \\
\Sigma\end{array}$} \\
\hline $\begin{array}{l}\text { - The association develops multiple partnerships } \\
\text { - The association seeks to maintain trusting relations with its partners } \\
\text { - External partners send failed entrepreneurs to the association } \\
\text { - The association puts the EER in touch with other external partners } \\
\text { - The mentor puts the EER in touch with the association's experts } \\
\text { - The association members share their address books to help the EER } \\
\text { - The President of the association acts as an interface and puts EER in touch with external resources } \\
\text { - The association collaborates with other associations that help post-bankruptcy entrepreneurs } \\
\text { - The association conducts lobbying activities } \\
\text { - The association uses the media, schools, etc. to convey a positive image of failure }\end{array}$ & Resilience system & & \\
\hline
\end{tabular}




\section{EMPIRICAL RESULTS}

In this section, we show that the post-bankruptcy entrepreneur's resilience process is linked not only to interactions between the entrepreneur and the association (through different tools), but also (indirectly) to interactions between the association and its environment (through a positive feedback loop for the entrepreneur).

\subsection{ASSOCIATION TOOLS AND PRINCIPLES TO PROMOTE RESILIENCE}

The 60.000 Rebonds association is designed to help entrepreneurs overcome the three aspects of the 'triple trauma' by providing:

1) Personal support: Enabling the entrepreneur to manage his or her bereavement from the failure and to be in a position to work towards a new career plan.

2) Professional support: Helping the entrepreneur to create and implement his or her new business venture in terms of marketing, commerce, accounting, finance, and so on.

3) Financial support: Putting the entrepreneur in touch with a professional consultant and finding accounts management and financial solutions.

More precisely, the association uses a certain number of individual and collective support tools to foster the resilience of recovering entrepreneurs (cf. Table 3):

1) Coaching: recovering entrepreneurs have 6 or 7 one-and-a-half hour coaching sessions once a fortnight. A qualified coach supports the entrepreneurs in their psychological reconstruction phase (to discuss their pain, mourn their loss, give them back their self-esteem and self-confidence, etc.). These sessions also help them to make sense of their bankruptcy, guiding them to recognise the internal and external causes, for instance, so as to draw useful lessons for the future. Through this objective re-reading of their story, recovering entrepreneurs are encouraged to challenge their own role and to assume responsibility for the failure. This helps them to understand that they have a certain degree of control over the events. Once this work has been done, the coach encourages them to begin thinking about a new career plan and what it would involve.

2) Exchange and Development Groups (EDG): Throughout the support process, the recovering entrepreneurs may take part in several EDG of around 2 hours, led by a coach from 60.000 Rebonds. The entrepreneurs talk about their past and present professional situation in front of 7 or 8 members of the association (experts or recovering entrepreneurs) with a range of skills and backgrounds. The different participants give them a critical assessment of the situation, which helps them to retroactively analyse their failure and to draw up the action plan needed to develop a new business idea.

3) Mentoring: An expert-volunteer helps the recovering entrepreneurs in operational terms, providing support to structure and develop their new business idea over a period that can last up to two years. If they do not know enough to help an entrepreneur with a specific point, the mentor puts him or her in touch with other experts from the association. ${ }^{1}$ When the mentor considers that the entrepreneurs' venture is sufficiently advanced, a committee of three expertvolunteers meet to help the former finalise the application he or she will present to the banks.

\footnotetext{
${ }^{1}$ From time to time, the association also organises speed-dating sessions to promote the transfer of expertise from experts to the recovering entrepreneurs.
} 
Table 3: Role of the association in the recovering entrepreneurs' resilience process

\begin{tabular}{|c|c|c|}
\hline $\begin{array}{l}\text { Dimensions } \\
\text { of resilience }\end{array}$ & $\begin{array}{c}\text { Association } \\
\text { tools }\end{array}$ & Verbatim $^{1}$ \\
\hline $\begin{array}{l}\text { Absorption } \\
\text { of the } \\
\text { emotional } \\
\text { shock }\end{array}$ & Coaching & $\begin{array}{l}\text { 'We begin by working on personal reconstruction at individual level. } \\
\text { Because all of them [the entrepreneurs who arrive at } 60.000 \text { Rebonds] } \\
\text { are in a state of depression, isolation, personal suffering, or even family } \\
\text { bereavement. In other words, it's a very difficult time! Because in general, } \\
\text { when you lose a company, you can easily lose all the rest: wife, everything } \\
\text { that goes with it' [interview - coach]. }\end{array}$ \\
\hline \multirow{2}{*}{$\begin{array}{l}\text { Intelligence } \\
\text { of the } \\
\text { failure }\end{array}$} & Coaching & $\begin{array}{l}\text { 'The coaching offers the recovering entrepreneurs a unique space to [...] } \\
\text { draw lessons from their experience, a key condition to get over the failure } \\
\text { [...]. A sympathetic ear during the sessions allows them to look at the real } \\
\text { facts, to analyse them so as to understand their own responsibility and to } \\
\text { fully accept it, while at the same time recognising what is not entirely their } \\
\text { fault [...]. This involves stepping back, becoming more lucid, and } \\
\text { highlighting the success factors for a potential new entrepreneurial } \\
\text { adventure' [website - volunteer]. }\end{array}$ \\
\hline & EDG & $\begin{array}{l}\text { '[In the EDG, there is] a sort of retroactive reflection on what happened. } \\
\text { In other words: Why did I fail? How? What aspects did I introduce? Why } \\
\text { did I set up this venture when perhaps I could have realised from the } \\
\text { outset that there were things that could impede its success? [...]. [We work } \\
\text { on] what went wrong. So that the psychic mechanisms do not return. In } \\
\text { fact, we know that as long as you don't accept your mistakes, you'll make } \\
\text { the same ones again...it's a vicious circle' [interview - coach]. }\end{array}$ \\
\hline \multirow{4}{*}{$\begin{array}{l}\text { New } \\
\text { professional } \\
\text { start }\end{array}$} & Coaching & $\begin{array}{l}\text { '[At the end of the coaching], options begin to appear [...]. At this point, } \\
\text { the entrepreneur begins to recover some power and has a choice. Because } \\
\text { up to that point he was completely stuck. And really, with very little } \\
\text { energy. So, there again, from the moment I begin to be able to choose and } \\
\text { to say to myself: 'Hey, I can do something new!', then the energy comes } \\
\text { back. And at this point, it's possible to work on the new business idea [...]. } \\
\text { Once he begins to let go and have this reconstruction of possible options, } \\
\text { then the entrepreneur enters another mindset [...]. He shifts from the } \\
\text { initial 'passive' attitude to one that says 'there, I'm ready for action!', } \\
\text { [conference - coach]. }\end{array}$ \\
\hline & EDG & $\begin{array}{l}\text { 'With } 60.000 \text { Rebonds I could take part in EDG that were really useful to } \\
\text { explain her professional problem to the people who take part in the } \\
\text { meeting and to find a solution and avenues for reflection about the } \\
\text { concrete case presented' [website - recovering entrepreneur]. }\end{array}$ \\
\hline & $\begin{array}{l}\text { Mentoring } \\
+ \\
\text { consultant- } \\
\text { expert }\end{array}$ & $\begin{array}{l}\text { '[My mentee] has now understood a certain number of things [...]. If you } \\
\text { have the equivalent of } 6 \text { FTP }+2 \text { FTP per sub-contracting company, } \\
\text { where } 3 \text { FTP would traditionally have been enough, you have a strong } \\
\text { chance of going belly up! So I tried to help him to see that. He had to cut } \\
\text { back on his staff's expenses. He's now laid off two of the six staff he had } \\
\text { at the outset. And he's going to make sure there's as little sub-contracting } \\
\text { as possible [...]. If I hadn't insisted on this staffing problem, he would } \\
\text { have preferred to ignore it!' [interview - mentor]. }\end{array}$ \\
\hline & $\begin{array}{l}\text { Banking } \\
\text { and } \\
\text { financial } \\
\text { engineering }\end{array}$ & $\begin{array}{l}\text { 'The association's services [...] [can include] financial support, putting } \\
\text { the recovering entrepreneurs in contact with a professional consultant } \\
\text { [and] implementing financial and accounts management solutions' } \\
\text { [processes - association]. }\end{array}$ \\
\hline
\end{tabular}

\footnotetext{
${ }^{1}$ For the sake of simplification, each verbatim presented here refers to one (and only one) $1^{\text {st }}$-order code among all the $1^{\text {st }}$-order codes associated with a specific $2^{\text {nd }}$-order theme in Table 2 . For instance, the first verbatim in Table 3 illustrates the $2^{\text {nd }}$-order theme named 'Shock absorption' in Table 2 (which includes nine different $1^{\text {st }}$-order codes) and is linked, more precisely, to the $1^{\text {st }}$-order code synthesized as follows: 'The association helps the EER to overcome their failure.'
} 
At the end of 24 months of support, recovering entrepreneurs become 'post-bankruptcy entrepreneurs'. At this point, their project should be sufficiently developed to be up and running. At the end of 2014, of the 25 entrepreneurs accompanied by the association at the national scale: 12 people had recreated a business, 6 people were in the process of a new entrepreneurial initiative and 7 people had become employees.

'Now [...] I've started another business. [...]. It took me almost six months to set up the venture [...]. Today, the message I'd like to pass on is that it's a real success! We can recover. We can go back into business again. It works' [conference - recovering entrepreneur].

However, the post-bankruptcy recovery of entrepreneurs is only possible if the association provides a propitious context. Above all, everything is done so that the recovering entrepreneur does not rush into a 'patch-up project' (or a 'repair-project') before completing the bereavement process of their past failure and drawing useful lessons from it for the future. Recovering entrepreneurs can get help to find a temporary job of some sort to give them time to think through their new business idea.

'You can't start a new business too fast. [You have to] avoid rushing into things with lack of hindsight or analysis. We have to take the question of time into account (even if it's difficult as you have no income after a bankruptcy). It takes at least three months of work and individual and personal coaching to really understand your mistakes and your strong points. On average, it takes between six months and two years for the new venture to be really rock solid' [web - founder].

However, there does not seem to be a purely sequential logic in the support given to recovering entrepreneurs: e.g. absorbing the emotional shock, then understanding the failure, and finally a new professional start. In practice, the association - notably through the coaches deliberately makes the recovering entrepreneurs seesaw between retrospective analysis and new career plans. During an EDG, a recovering entrepreneur will be asked: 'What have you learnt from this experience? What could be a barrier to your new experience?' [observation - coach]. The discussion thus focuses on analysing the reasons for failure and any psychological obstacles for recovering entrepreneurs (looking back), after which the entrepreneurs are asked to write an outline plan of action for the next EDG (moving forward).

The diversity of participants in the EDG is a great advantage in this continual to-ing and fro-ing process. The coach thus takes an introspective and retro-analytical approach, while the experts tend to ask the entrepreneurs about the technical aspects of their new business idea. A sequential approach is less desirable in that the 'reconstruction of the personal base' of recovering entrepreneurs is a long-term process. Thus, with some individuals we observed 'elastic reactions' (i.e. an unconscious projection of past emotions onto the present situation) that hamper the development of their new business idea. Criticisms made during an EDG can reopen the old wounds of recovering entrepreneurs for example, something we observed in the tears and defensive reactions of one of them during an EDG. This is why personal and professional support is provided in parallel. The association adapts, in fact, to the specific profile of each recovering entrepreneur. Moreover, the flexibility of the process is fully assumed by the association in that it fosters an atmosphere of psychological safety.

'What I discovered is the world of failed entrepreneurs with really considerable differences. So we can't apply processes or methods in a drastic way since this world is made up of a thousand diversities! [...] I introduced processes throughout the organisation, but they're not strict [...]. These people are so different that we can't shut them in boxes. So we're pretty free with the processes as they exist today [...]. I know that it's not strict enough but for the moment we can't do anything else! We don't yet have the benefit of hindsight! Some things will certainly get better with time [...]. I prefer it to be a little more open and for people to feel good! [...]. It's very important that people feel safe [...]. You can never put people into boxes. Each person has their own way of behaving and it's better to make sure [...] that we uphold the association's values. And, good heavens, if something isn't done according to the rule book by someone or other, it's not the most important thing! [...]. Flexibility is essential!' [interview president]. 
The way the association considers recovering entrepreneurs is also quite unique. In effect, there is no hierarchy between expert-volunteers and recovering entrepreneurs. A sign of this determination to develop relationships on an equal footing is the fact that all the volunteers speak very freely about their own past failures. The story of Philippe Rambaud's bankruptcy is wellknown to everyone in the association for instance. Similarly, the association's president and vicepresident speak openly about their own meltdown to new members. This 'baring of the soul' immediately helps to create a climate of trust for recovering entrepreneurs. They feel supported by peers in a better position to understand them, and consequently they open up more easily. In addition, sitting in front of people who have already bounced back gives them grounds for hope ('positive mirror effect').

'With Philippe Rambaud and the others, it's interesting in the sense that when we speak to them about what they're feeling, the problems they encounter on a daily basis, it's things they've experienced. You can feel it. It's reassuring and comforting. We're more ready to listen to what they've experienced [...]. Going into liquidation is a truly unique moment. And you can use all the words, all the formulas, etc., but if you haven't experienced it, then you can't really understand what it is! I'm quite sure about that. And meeting people who've lived through it and who found - at a given moment - the means to move onto something else, to recover and move forward, well of course it's positive! We speak the same language, we understand one another [...]. We can say whatever we've got on our chest. And people listen to you. And in theory, no one judges you' [interview - recovering entrepreneurs].

In its determination to put the recovering entrepreneurs on an equal footing with the volunteers, the association also gives them the role of expert, getting them to use their experience to help other entrepreneurs during the EDG. In effect, as the founder of 60.000 Rebonds explained, there is no question of 'patients' on one side and 'doctors' on the other. The association's approach gives recovering entrepreneurs a highly empowering role that promotes the healing of their post-bankruptcy damage to the ego. The mirror effect also helps them to feel less alone, putting things into perspective with regard to their own past failure and helping them to regain confidence and feed off the different narratives in order to understand their experience from a new angle.

'They come out of their isolation [...]. They realise that they're not alone: 'Everyone there around the table, they did the same as me. So I shake off all this negativity I have about myself. I stop feeling guilty. Because, finally, my mate sitting next to me also failed' [...]. It makes for transfers and mirror effects [...]. Even if they're in a difficult situation, they still have this role of expert in some EDG [...]. It's very rewarding for them. Because the damage to the ego is so important after the failure that being able to say: 'Ah, I know the answer there; perhaps I can give some useful advice and maybe I can have a positive reflection for the others, etc. 'I'm back in a position where I'm also valued a bit, in my position, in everything that I might represent in the eyes of the other [...]. [For a recovering entrepreneur] it even helps the ego to be able to say: 'I can help someone!' [...]. For them, adopting this position means saying: 'There, I can also give something!' [interview - coach].

However, this type of projection can also make recovering entrepreneurs highly critical of their peers. In effect, the weaknesses they think they see in other business ventures takes them back to their own past failure that still lurks in the background. In their desire to help other recovering entrepreneurs, some can make very harsh judgements without always measuring the impact of their words. Thus, the president of the association and the coaches stress the importance of a climate of helpfulness at the beginning of each EDG so that any differences of opinion occur in a positive way, since the EDG should not serve as a pressure valve.

'The EDG is difficult! [...] There may be some aggressiveness in the EDG. People don't realise! Sympathy is not always innate! When we want to help others, we can sometimes be a bit directive [...]. Still, we need to question the business plan or the ideas of the person sitting opposite [...]. Personally, I felt I was being attacked [...]. If you're not very sure of yourself, it can have the opposite effect [from the one desired]. We might reject what the others say [...]. I took an EDG badly when the people were really aggressive. I don't know if they realised [...]. I find that people are more careful now. [The president] insisted on this point. And there's more sympathy than before!' [interview - recovering entrepreneur]. 


\subsection{MANAGING THE ASSOCIATION'S IMAGE WITHIN A SYSTEM OF RESILIENCE}

Initially, the association was financially supported by three important partners (City of Bordeaux, Crédit Agricole Aquitaine and EY Bordeaux) (cf. supra). EY also provides the association with skills patronage (e.g. legal and accounting advice). For its part, Crédit Agricole Aquitaine is supposed to give recovering entrepreneurs whose project has been validated by the selection committee an appointment with a professional consultant, open a professional bank account and provide $20 \%$ of the capital and investment needed for the recovery (with a ceiling of 10,000 euros) in order to start a banking pool. The Crédit Agricole bank nonetheless has the right of veto regarding the economic viability of the business venture.

'The association has a good address book. There are partnerships with the Crédit Agricole bank and others [...]. This helps some to get a bank account again, to get a bank card, maybe even to benefit from some funding, etc. Personally, I find there's real added value, because it's true that it's complicated to go and see a banker once you've been on the black list of business owners that have gone into liquidation [laughs]!' [interview - recovering entrepreneur].

Moreover, 60.000 Rebonds collaborates with many other partners (e.g. endowment funds, associations offering business venture and financial support to entrepreneurs, job search associations, an organisation that helps associations supporting entrepreneurial initiatives, a fundraising platform devoted to associations, crowd funding organisations, etc.). The association has thus created a 'star system' [observation - volunteer] in the field to share and exchange expertise. The 60.000 Rebonds website describes its links with 'the local and regional ecosystem.' One volunteer in the association focuses entirely on the search for partnerships. At each steering committee meeting, a potential partner of 60.000 Rebonds is invited to present its structure and activities.

'We need many complementary associations so that our action is surrounded and fully efficient.' [moral report - association].

The association has now created a significant network across France. Thus, a postbankruptcy entrepreneur arriving at 60.000 Rebonds who wishes to find paid employment will be given the addresses of associations that help people to find jobs. In addition, 60.000 Rebonds works with other organisations which provide services and skills useful to recovering entrepreneurs. At the beginning of the support process, for instance, the association may put a recovering entrepreneur in touch with other services if the help required is outside their field of expertise (e.g. psychiatric help, social emergency, etc.). Similarly, at the end of the support process, 60.000 Rebonds relies on various structures (e.g. MyMajorCompany) to finance the entrepreneurs' business ventures.

'When they're in a difficult situation, when they have virtually no income, their wife doesn't work and they have four children to support, it's very complicated. And they're often in a hurry to find a job quickly [...]. We realised we didn't help them [by going to quickly], but on the other hand, there were social priorities. And we ask associations that work more or less in social areas to help us out with social assistants. To help them get assistance, some money to live on [...]. To at least try to ease the financial burden a bit. It's important to realise that most of the time they have catastrophic debts. And they don't always know what fate has in store for them! [...]. We immediately get help from another association. At once! We're very aware of these precarious situations and we try not to let them down!' [interview - coach].

Keen to improve its processes and to make its initiative more credible, the association has also conducted benchmarking operations with an association in existence for over 30 years that has developed a highly structured support methodology which is highly valued by its beneficiaries. The serious and professional image conveyed by 60.000 Rebonds is indeed crucial in the entrepreneur's post-bankruptcy recovery process as failed entrepreneurs are traditionally stigmatised. According to an IPSOS survey (2013: 7), 'the French consider that we too often 
discredit people who experience failure in their professional life (83\%). They note that in France, getting a second chance is more the exception than the rule, especially for business owners. $69 \%$ of those questioned said that we don't give failed entrepreneurs sufficient chance.' In our case study, recovering entrepreneurs supported by 60.000 Rebonds are perceived far more favourably in view of the association's support, particularly by bankers. Thus, the positive image projected by the association reflects onto the recovering entrepreneurs who can take advantage of support (especially financial) that would be virtually impossible for them to access under normal circumstances. This can be interpreted as a form of positive feedback loop, in the sense of the general system theory (Bertalanffy, 1968).

'Earlier, an [entrepreneur who took part in this conference] explained to us that the Crédit Agricole bank helped him. I'd like to remain modest [...], which means first and foremost saying that if he had come without 60.000 Rebonds... and I think that he already did come a first time and he found it difficult to get anyone to listen to his idea... Then he went to 60.000 Rebonds [...] and with everything that that implies in terms of support for recovering business owners. And there, straightaway, the banker looks at the application in a different way... because it's not at all sure that we would have accepted his business idea if he'd been on his own!' [conference - General Manager Crédit Agricole Aquitaine].

More generally, the association realises that the recovery of post-bankruptcy entrepreneurs involves developing a more favourable socioeconomic context for them at national level. The association thus intends 'to send messages on both a political and a social level' [interview - vice-president]. In other words, the association wants to 'change French society's vision of entrepreneurial failure' [charter - association]. To this end, the association organizes numerous conferences ${ }^{1}$ (Grandes Ecoles, MEDEF, incubators, start-up owners, manager network, etc.) and interviews with Philippe Rambaud on the topic of failure and recovery in order to convey a more positive image of failure in France. The different press article titles below illustrate the positive fallout of the public relations campaign run by 60.000 Rebonds.

- La faillite ne doit plus être tabou, 60.000 Rebonds s'y active (Bankruptcy should no longer be taboo, 60.000 Rebonds is working on it) [press - Ouest France].

- Entrepreneuriat: la faillite, voie du succès? (Entrepreneurship: bankruptcy, the way to success?) [press regional decision makers].

- Bordeaux: comment l'asso du rebond veut mettre la faillite en faillite (Bordeaux: how the recovery association wants to make bankruptcy bankrupt) [press - La Tribune].

- Et si échouer devenait le meilleur tremplin des dirigeants? (What if failing was the best springboard for business leaders?) [press - Les Échos Business].

- Philippe Rambaud a fait de la faillite une ressource professionnelle (Philippe Rambaud has made failure a professional resource) [press - Le Monde].

- Philippe Rambaud redonne des couleurs aux entrepreneurs qui ont échoué (Philippe Rambaud gives failed entrepreneurs new hope) [press - L'Express].

- Rebondir après un échec (Recovering after a failure) [press - Les Échos Business].

- Y'a-t-il une deuxième vie après une faillite? (Is there another life after bankruptcy?) [press - Le Figaro].

- Faillite d'entreprise: éviter les faux rebonds (Bankruptcy - avoiding false recoveries) [press - Sud Ouest].

- 60.000 Rebonds: enfin un réseau de soutien après une faillite (60.000 Rebonds: at last a support network after a bankruptcy) [press - Le Journal des Entreprises].

Moreover, Philippe Rambaud helped to draw up the charter of territorial deployment of recovery conferences in January 2014, proposed by Fleur Pellerin, at the time Minister for SMEs, Innovation and the Digital Economy, an illustration of the way 60.000 Rebonds lobbies the public authorities. Philippe Rambaud is also behind the decision taken by Fleur Pellerin to revoke the 040 indicator in September 2013, ${ }^{2}$ which means that entrepreneurs who have gone bankrupt should now be able to obtain a loan from banks more easily. Similarly, Fleur Pellerin asked

\footnotetext{
${ }^{1}$ Philippe Rambaud had held 32 conferences by 17/03/2014.

2 This indicator lists entrepreneurs who have been served with a judicial liquidation order in the last three years for the Banque de France.
} 
Philippe Rambaud to write an official report on ways to help bankrupt entrepreneurs in France to recover.

'In view of its expertise, in 2013, 60000 Rebonds had the honour of putting forward a series of proposals to the Assizes working groups on Entrepreneurship organised by the Minister of the Economy and Finance (Mme Fleur Pellerin, Minister in charge of SMEs, Innovation and the Digital Economy) to help failed entrepreneurs to make a recovery. One proposal to revoke the 040 Banque de France indicator was one of ten measures retained by the French President, with the publication of a decree on 2 September 2013. The first of many victories we hope!' [association website - founder].

To find other partners (especially financiers) and continue to have a national impact, the association needs to successfully manage the image it gives to outside observers (lawmakers, potential donors, business angels, media, etc.). For instance, in 2016, Philippe Rambaud convinced the famous Mulliez family to financially support the 60.000 Rebonds association (Guillaume Mulliez became, on this occasion, president of the association at the national level). In fact, the more positive the image of 60.000 Rebonds, the more willing external partners will be to help the association and, indirectly, recovering entrepreneurs. This is why Philippe Rambaud turned to 'major stars' and 'opinion leaders' to back his activities (e.g. two major firms, EY and Crédit Agricole bank, are the association's administrators; Franck Riboud, the CEO of Danone group, took part in the national recovery forum organised by the association in 2014, as did the mayor of Bordeaux, Alain Juppé, and the famous economist and writer, Jacques Attali, is an honorary member of the association, etc.).

In addition, the association uses its recovering entrepreneurs to convey a positive image of its activities. In effect, entrepreneurs who are the most advanced in their recovery process are invited to speak at different events as well as on the association's website where they publicly express their gratitude to 60.000 Rebonds (e.g. 'I owe my recovery uniquely to the 60.000 Rebonds association'), especially as it allows them to speak about their new business and helps to raise their profile. ${ }^{1}$ Recognition and consideration are also part of the 'basic association values' [charter - association]. We should also note that the emphasis on external communication sometimes leads 60.000 Rebonds to use recovering entrepreneurs as standard bearers whose comeback is only marginally due to the support processes it offers.

'My purpose [when I contacted Philippe Rambaud] was not necessarily to get help. My three companies went bankrupt in 2011 [...]. It was all behind me at any rate. I started a new company in 2010. So I had already begun the recovery process before going bankrupt [...]. I came to the association more in this frame of mind: filing for bankruptcy is very traumatic for a business owner, I experienced it, I went through it, if I can help in one way or another, I'd like to take part! [...]. I'm a bit unusual [...]. In fact to be honest I've never used the association's experts! [...] 60.000 Rebonds helped me to talk very positively about my business: I was able to take part in a round table conference with Alain Juppé in Bordeaux on 11 July [2013] and to talk about my experience and the help I got from the association. And I also had the real honour of taking part in a meeting in Matignon with Jean-Marc Ayrault [Prime Minister at the time] and Fleur Pellerin on 17 July 2013 with 11 other entrepreneurs to spread the word' [interview + website - recovering entrepreneur].

Sometimes, the association also exaggerates facts when presenting some recovering entrepreneurs. For example, during one conference the audience were told that one of them ' $h a d$ made a marvellous recovery' [conference - founder], even though she had in fact simply found a 'basic job, just to get back on [her] feet a bit' [conference - recovering entrepreneurs], and had just began her notice period following a layoff. In the end, image management by 60.000 Rebonds leads to the paradox that the association actively fights against the negative image of failure in our society, while trying to convince others of its own success at any price. Moreover, while the

\footnotetext{
${ }^{1}$ For instance, during the national recovery forum organised by the association in November 2014, one recovering entrepreneur used his talk about his experience to promote his business. Similarly, the written experiences of a recovering entrepreneur, available on the internet, have a link to the company's website.
} 
association readily talks about the success of some recovering entrepreneurs and capitalises on the stories to increase its renown, it does not, on the other hand, wish to be associated with failure.

Thus, the 60.000 Rebonds charter states that there is 'no obligation for results.' Consequently, 60.000 Rebonds success indicators do not include the sustainability of businesses created by the recovering entrepreneurs. During a steering committee meeting, Philippe Rambaud noted, as an aside, that: 'the processes are more important than the results.' In practice, 'in the event of failure of recovering entrepreneurs, the candidate cannot prosecute the association or its members' [charter - association]. The association takes refuge behind the fact that 'recruitment is not elitist' [observation - founder] and that recovering entrepreneurs alone are responsible for their operational decisions ( 60.000 Rebonds supports them, but cannot decide in their place). Figure 2, below, summarises our different empirical results. 
Figure 2: Resilience of the post-bankruptcy entrepreneur within the 60.000 Rebonds association

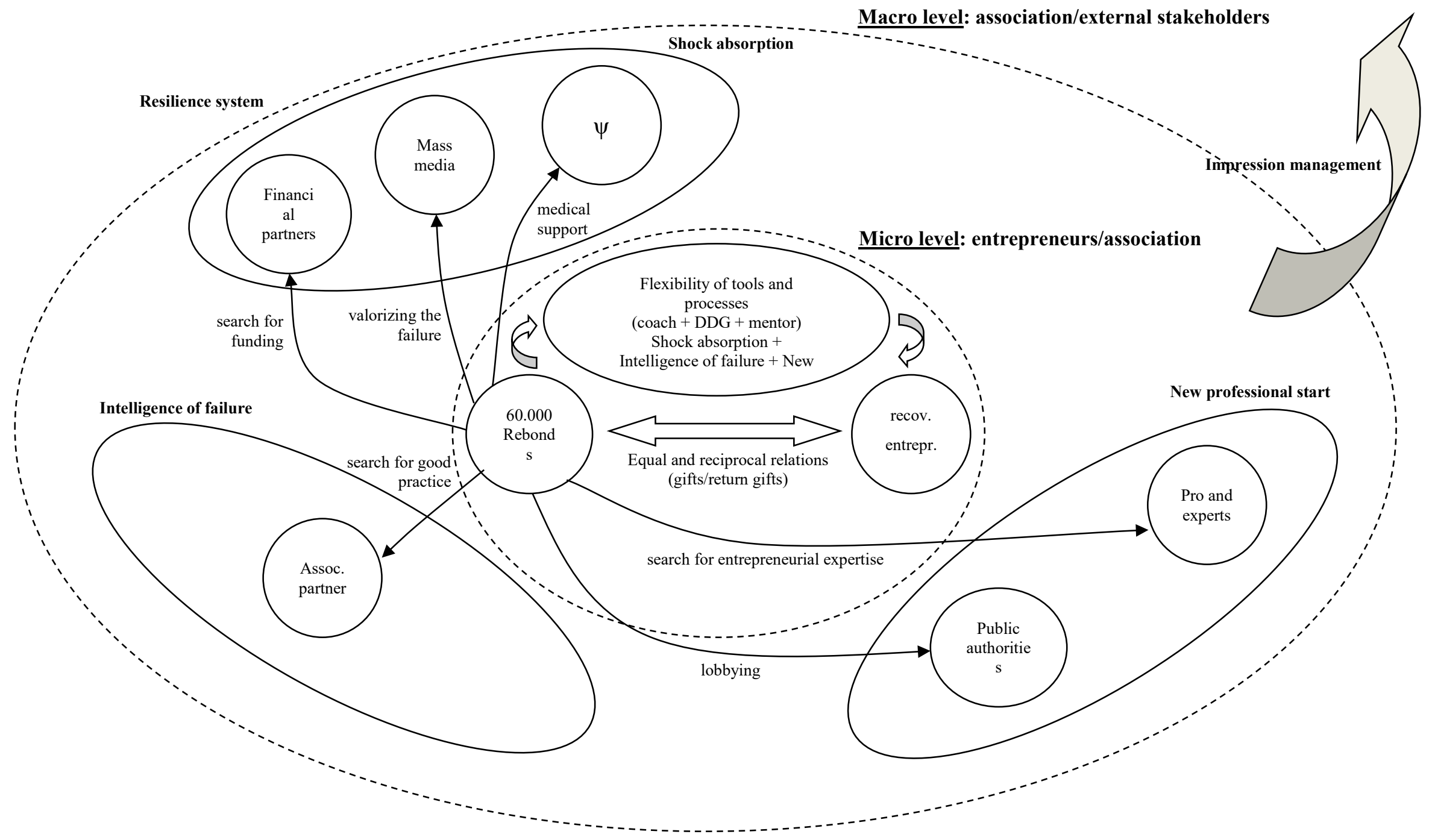




\section{DISCUSSION}

Our analysis highlights the importance of interaction between post-bankruptcy entrepreneurs and their social environment in the individual resilience process (Bernard \& Barbosa, 2016 ; Egeland, et al., 1993; Cyrulnik, 2011; Ayala \& Manzano, 2014). Our original contribution comes from the fact that we get inside the black box of this entrepreneur/environment interaction by adopting the perspective of the external tutor rather than the more traditional lens of the failed entrepreneur (Bullough, et al., 2014; Cope, 2011; Hayward, et al., 2010). Our approach is all the more original in that it offers an empirical illustration of the concept of resilience, a notion that generally gives rise to conceptual reflections (Sutcliffe \& Vogus, 2003; Bhamraa, et al., 2011). In this context, we may note that our review of the literature resulted in an analytical framework of individual resilience that highlighted three dimensions: 1) absorption of the emotional shock triggered by the failure, 2) the development of a real intelligence of failure and 3) the launch of a new business venture following the failure. Consequently, we help to fill the gap, frequently noted in the literature (Bernard \& Barbosa, 2016 ; Mohaupt, 2009; Ayala \& Manzano, 2014), regarding the operationalisation of the concept of resilience.

We conclude that the tutor may act - directly or indirectly - on all three dimensions of the resilience process by way of dedicated tools (coaching, Exchange and Development Groups, mentoring, speed-dating, etc.) and the deployment of a network of partners. In other words, there are different locus of 'resilience making'. Furthermore, the tutor appears to play a role in each of the three stages of postfailure trauma identified by Cope (2011). In the case of 60.000 Rebonds, the entrepreneur's psychological, financial and social traumas are dealt with respectively through coaching sessions, being put in touch with a bank partner, and numerous talks on the virtues of failure, to give just a few examples. The tutor may also help the entrepreneur to develop crucial resilience tools such as the capacity to adopt a positive attitude in the face of adversity (Ayala \& Manzano, 2013), as well as their sense of selfefficacy (Bandura, 1977). By highlighting the tutor's role in transforming and helping the recovering entrepreneur to mature (Cyrulnik, 2011), we show that resilience is not a fixed attribute for the entrepreneur (Bullough \& Renko, 2013) and that it may, on the contrary, be developed, encouraged and strengthened by the tutor (Ayala \& Manzano, 2013; Bullough \& Renko, 2013; Bullough, et al., 2014).

In this context, our work highlights the regulatory role of the tutor in the entrepreneur's resilience process. Guidance operates on different levels. First, the tutor sets the pace of the resilience process. More specifically, the tutor deliberately incites the recovering entrepreneur to switch between 'loss orientation' (looking back) and 'restoration orientation' (moving forward), the two ways of coping identified by Shepherd (2003, 2009), following Stroebe \& Schut (1999). In other words, the tutor regulates the dual recovery process identified by the author. Tutor-led regulation is generally easier to manage than self-regulation by the entrepreneur as the tutor is not 'polluted' by the negative emotions linked to failure (Cope, 2011; Shepherd, 2003; Ucbasaran, et al., 2013; Singh, et al., 2015). At the same time, the tutor encourages post-bankruptcy entrepreneurs to face up to their past failure and to review the experience in a positive light, while helping them to plan for a new business idea. If we remember that the dual process model of coping with bereavement is a dynamic, back-and-forth process, which 'needs dosage' (Stroebe \& Schut, 1999: 220), we can conclude that the tutor is the one who handles this dosage.

One key challenge is to prevent the entrepreneurs from leaping into a new project (moving forward) too fast, which would simply impact on secondary sources of stress, such as money problems, boredom related to inactivity, and damaged reputation (Shepherd, 2003). With the tutor's help, recovering entrepreneurs alternate between critical reflection and reflective action (Cope, 2011). This implies that the three dimensions of the resilience process identified in the study (cf. supra) should not be envisaged as stages clearly separated in time, as in a linear and sequential vision. Instead, shock absorption, intelligence of the failure and professional comeback can be considered as 'ingredients' introduced by the tutor to help the entrepreneurs work towards resilience.

In its role of regulator of the resilience process, the tutor also defines the role of each player in the process. In this respect, recovering entrepreneurs are not considered as helpless individuals or patients. On the contrary, the recovery dynamic fits into a scenario of gifts and return gifts, as in sociology studies on reciprocity (Mauss, 1954). This assumes that the representative figure of the tutor (i.e. the volunteers in our case study) and the recovering entrepreneurs are seen as equals. Giving the recovering entrepreneur a role of expert in parallel with the support he or she receives from the 
association helps repair the considerable damage to the ego by implicitly removing the heuristic model that assimilates failure with incompetence. The tutor fosters the recovery dynamic by showing failed entrepreneurs that they can once again have confidence in their skills, their expertise and their judgement. Absence of hierarchy between the tutor and the recovering entrepreneurs also helps to create a relationship based on trust that is equally important in the entrepreneur's post-bankruptcy resilience process. When the representative figures of the tutor talk openly about their past failures, it legitimizes their support for the recovering entrepreneurs. Paradoxically, the past failure may thus be viewed as a sign of legitimacy by the post-bankruptcy entrepreneur, given the tendency towards projection and the mirror effect (Criss, Aue \& Kihç, 2014).

Management of the resilience process also implies that the tutor determines the acceptable degree of contradiction in order to foster a genuine intelligence of failure (Antonovsky, 1998; Ayala \& Manzano, 2014). In effect, the tutor is there to encourage critical reflection on the recovering entrepreneur's past and present projects (Cope, 2011). This includes organising discussions with peers and experts, designed to develop the entrepreneurs' awareness of any self-complacency in their analysis (Miller \& Ross, 1975). Nonetheless, the tutor also needs to ensure that the critical focus on the entrepreneur remains sympathetic and is not simply used as a pressure valve. The tutor therefore needs to create an atmosphere of psychological safety when coordinating the different discussions (Tucker \& Edmondson, 2003). In this regard, Shepherd (2003) stresses the importance of putting such entrepreneurs in touch with third parties to help them to overcome their post-bankruptcy trauma. Our research indicates that it is preferable to interact with peers (i.e. people who have experienced the same situation). In effect, this helps to de-dramatize the failure and to develop an objective view of the experience. This is in line with the findings of Bullough \& Renko (2013) who emphasise the virtues of peer-to-peer coaching.

Finally, the tutor's role as a regulator in the entrepreneur's post-bankruptcy recovery dynamic requires some fine-tuning with respect to the procedures. Resilience is certainly not an inherent personality trait (Bullough \& Renko, 2013), but will develop differently according to the entrepreneur profile. Thus, the tutor needs to be flexible in the use of the support tools adopted to help people recover.

Our study also shows that creating a context favourable to the entrepreneur's post-bankruptcy resilience requires more than the tutor alone when the latter is linked to an organisation, as in our study. In other words, a dyadic relationship between the recovering entrepreneur and the tutor is insufficient. On the contrary, by illustrating the importance of the tutor's links with constitutive and associative partners, the public authorities and the media, we highlight the existence of a real resilience system. More precisely, the legitimization of the association (e.g. with bankers) has indirect consequences on the individual's resilience process through the positive feedback loop (e.g. facilitated access to financial resources) (Bertalanffy, 1968). This reticular approach by the tutor is all the more crucial since entrepreneurs often see their network of contacts disintegrate following a bankruptcy (Ucbasaran, et al., 2013; Singh, et al., 2015). The 'star system' developed by the tutor may thus be perceived as an answer to the entrepreneur's post-bankruptcy isolation (Cyrulnik, 2011).

To nurture the recovery dynamic of entrepreneurs in a situation of failure, the tutor must constantly oscillate between operational (i.e. the micro level of support for entrepreneurs) and strategic support (i.e. the macro level of communication and lobbying with external stakeholders). This dynamic also requires subsequently managing how the tutor is viewed by external observers (Bozzolan, Cho \& Michelon, 2015) through reassurance and persuading observers of the interest of the support process. Indeed, the more positive the tutor's image, the more positively entrepreneurs supported by the tutor will be perceived by potential partners (especially financiers) through the so-called halo effect (Madden, Roth \& Dillon, 2012). This point is all the more important in that the failed entrepreneur is traditionally a victim of professional stigmatisation (Bacq, et al., 2009; Sutton \& Callahan, 1987; Cope, 2011; Singh, et al., 2015).

Again, the way the tutor manages the impressions of external stakeholders is based on reciprocity of the 'gifts and return gifts' type (Mauss, 1954). Similarly, standard-bearing entrepreneurs will publicly express their gratitude to the tutor (in the form of storytelling) for the help and assistance provided, which in turn makes the tutor and the process more credible. Paradoxically, this may lead the tutor to appropriate commonly used codes of society in its media messages (namely, promotion of success at any cost and rejection of failure), which it would reject in other circumstances. In other words, oscillation between operational and strategic courses of action by the tutor may induce it to accept some 
trade-offs. For instance, on the one hand, the processes and formal nature of the tutor are intended to strengthen its legitimacy with external partners while, on the other, it is essential to use the guidelines flexibly in order to create a psychologically reassuring environment for recovering entrepreneurs (Tucker \& Edmondson, 2003). In this sense, in positioning the cursor at the right point, the tutor of resilience may be perceived as an intermediary between contradictory forms of thinking and action (Latour, 2005).

\section{CONCLUSION}

Our study focuses on an issue that has had little coverage in the literature on entrepreneurship to date, namely, the role of the tutor in the recovery of post-bankruptcy entrepreneurs. To this end, we conducted a qualitative case study (Yin, 1990) of a non-profit making association, 60.000 Rebonds, that offers a 'second chance' (Bacq, et al., 2009 ; De Hoe \& Janssen, 2014 ; Singh, et al., 2015) to entrepreneurs in a situation of failure by giving them personal, professional and financial support. Considering this structure as an external collective tutor, we highlight the role of the social environment in the recovery process of entrepreneurs in a situation of failure (Shepherd, 2003). This is the main difference between our study and prior research that has tended to focus more on the bankrupt individual (Bullough, et al., 2014; Cope, 2011; Hayward, et al., 2010).

More specifically, our study shows how the tutor alternates between an operational role (i.e. the micro level of interaction with the entrepreneur) and a strategic role (i.e. the macro level of interaction with external stakeholders), which at times conflict. At micro level, we take an in-depth look at the regulatory impact of the tutor on the entrepreneur's post-bankruptcy resilience process. For instance, the tutor appears to set the pace of the recovery process by regulating the oscillation between 'looking back' and 'moving forward.' At macro level, we show that the tutor fits into a resilience system in the sense that it relies on other partners to give entrepreneurs effective support, since direct interaction with the latter alone is insufficient. The tutor must therefore optimise its image with regard to its external stakeholders in order to create a favourable context for the resilience of recovering entrepreneurs via the halo effect.

From our theoretical results, we can also infer recommendations at a managerial level. In particular, following De Hoe \& Janssen (2014), we highlight here the importance of personal, professional and financial support for helping post-bankruptcy entrepreneurs to bounce back. In particular, psychological support should no longer be taboo and seen (implicitly) as a sign of weakness. We also show in this article that an association with such a vocation must not only help entrepreneurs, but should also act on the environment in order to change the social representations of entrepreneurial failure (for example, through conferences). Furthermore, we point out that a key success factor of this type of association is the perceived legitimacy of its members to create a relationship of trust with postbankruptcy entrepreneurs. More precisely, to be seen as peers, association's members must previously have faced entrepreneurial failure too. This also helps to play down the bankrupt in the eyes of the entrepreneurs supported by the association.

Our study nonetheless has some limitations. In particular, our empirical analysis was conducted in France, a country where failure is highly stigmatised (IPSOS, 2013). Thus, some of the actions undertaken by the 60.000 Rebonds association may be of less interest in a country like the United States, for example. As an article in the New York Times on 8 November 2014 pointed out, celebrating failure has become so common across the Atlantic, especially in Silicon Valley, that there is perhaps no longer a need for conferences on the topic. Our study shows that more research is required, however. In particular, it would be interesting to study the post-bankruptcy path of entrepreneurs using the life story method (Thompson, 2004), which is very well adapted to providing more insights into the resilience process. This would also help us to pursue our exploration of the operationalisation of the concept, initiated in the present article. 


\section{REFERENCES}

ANTONOVSKY A. (1998), "The Sense of Coherence: An Historical and Future Perspective”, In H. MCCUBBIN E., THOMPSON A., THOMPSON, J. FROMER (Eds.), Stress, Coping, and Health in Families: Sense of Coherence and Resiliency (p. 3-20), Thousand Oaks, CA: Sage.

ARNAUT M. (2015), Psychologie de la résilience, Paris : Armand Colin.

AYALA J.-C., MANZANO G. (2014), "The resilience of the entrepreneur. Influence on the success of the business. A longitudinal analysis", Journal of Economic Psychology, n²42, p.126-135.

BACQ S., GIACOMIN O., JANSSEN F. (2009), "L'échec et la seconde chance”, In F. JANSSEN (Ed.), Entreprendre : Une introduction à l'entrepreneuriat (pp. 255-264), Bruxelles, De Boeck.

BANDURA A. (1977), Social learning theory, New York: General Learning Press.

BARON R., MARKMAN G. (2000), "Beyond social capital: How social skills can enhance entrepreneurs' success", Academy of Management Executive, vol.14, n¹, p.106-116.

BERNARD M.-J., BARBOSA S. (2016), "Resilience and entrepreneurship: A dynamic and biographical approach to the entrepreneurial act", M@n@gement, vol. 19, n², p.89-123.

BERTALANFFY L. (1968), General system theory: Foundations, development, applications, George Braziller, Inc.

BHAMRAA, R., DANIAB, S. \& BURNARDA, K. (2011), "Resilience: the concept, a literature review and future directions", International Journal of Production Research, vol. 49, n 18 , p. 5375-5393.

BLACKBURN R., KOVALAINEN A. (2009), "Researching small firms and entrepreneurship: past, present and future", International Journal of Management Reviews, vol.11, n², p.127-148.

BONANNO G. (2004), "Loss, Trauma, and Human Resilience. Have We Underestimated the Human Capacity to Thrive After Extremely Aversive Events?", American Psychologist, vol.59, n¹, p.20-28.

BOZZOLAN S., CHO C., MICHELON G. (2015), "Impression Management and Organizational Audiences: The Fiat Group Case", Journal of Business Ethics, vol.126, n¹, p.143-165.

BREWER M., HEWSTONE M. (2004), Social cognition (perspectives on social psychology), Oxford: Blackwell.

BULLOUGH A., RENKO M., MYATT, T. (2014), "Danger Zone Entrepreneurs: The Importance of Resilience and Self-Efficacy for Entrepreneurial Intentions", Entrepreneurship Theory and Practice, vol.38, n³, p.473-499.

BULLOUGH A., RENKO, M. (2013), "Entrepreneurial resilience during challenging times”, Business Horizons, vol.56, n³, p.343-350.

BURNS R., ANSTEY K. (2010), “The Connor-Davidson Resilience Scale (CD-RISC): Testing the invariance of a uni-dimensional resilience measure that is independent of positive and negative affect", Personality and Individual Differences, vol.48, $\mathrm{n}^{\circ} 5$, p.527-531.

BYRNE O., SHEPHERD D. (2015), "Different strokes for different folks: Entrepreneurial narratives of emotion, cognition, and making sense of business failure", Entrepreneurship Theory and Practice, vol.39, ${ }^{\circ} 2$, p.375-405.

CARDON M., MCGRATH R. (1999), "When the going gets tough: Toward a psychology of entrepreneurial failure and re-motivation". Paper presented at the Frontiers of Entrepreneurship Research Conference, Babson College, Wellesley, MA.

CARDON M., STEVENS C., POTTER D. (2011), "Misfortunes or mistakes? Cultural sensemaking of entrepreneurial failure", Journal of Business Venturing, vol.26, n¹, p.79-92.

CARDON M., ZIETSMA C., SAPARITO P., MATHERNE B., DAVIS, C. (2005), "A tale of passion: new insights into entrepreneurship from a parenthood metaphor", Journal of Business Venturing, vol.20, $\mathrm{n}^{\circ} 1, \mathrm{p} .23-45$.

CONNOR K., DAVIDSON J. (2003), "Development of a new resilience scale: The Connor-Davidson Resilience Scale (CD-RISC)", Depression and Anxiety, vol.18, n², p.76-82.

COPE J. (2011), "Entrepreneurial learning from failure: An interpretative phenomenological analysis", Journal of Business Venturing, vol.26, n 6 , p.604-623.

COPE J., CAVE F., ECCLES S. (2004), "Attitudes of venture capital investors towards entrepreneurs with previous business failure", Venture Capital, vol.6, n²/3, p.147-172.

COUTU D. (2002), "How resilience works", Harvard Business Review, vol.80, n5, p.46-56.

CRISS A., AUE W., KILIÇ, A. (2014), "Age and response bias: Evidence from the strengthbased mirror effect”, Quarterly Journal of Experimental Psychology, vol.67, n10, p.1910-1924. 
CYRULNIK B. (2011), Resilience: How Your Inner Strength Can Set You Free from the Past, J.P. Tarcher/Penguin.

DAVIDSON R. (2009), "More than 'Just Coping': The Antecedents and Dynamics of Resilience in a Qualitative Longitudinal Study", Social Policy and Society, vol.8, n 1, p.115-125.

DE HOE R., JANSSEN F. (2014), "L'échec entrepreneurial : une voie de succès futur ?", In G. LECOINTRE (Ed.) Le Grand Livre de l'Economie PME (pp. 177-195), Issy-les-Moulineaux, Gualino. DU PLESSIS A., VAN BREDA A. (2001), "Resilience Theory: a Literature Review”, in report from South African Military Health Service, Military Psychological Institute, Social Work Research and Development, p.1-54.

EGELAND B., CARLSON E., SROUFE L. (1993), "Resilience as process", Development and Psychopathology, vol.5, n 4 , p.517-528.

FREDRICKSON B. (1998), "What good are positive emotions?", Review of General Psychology, vol.2, n³, p.300-319.

FREDRICKSON B., TUGADE M., WAUGH C., LARKIN G. (2003), "What good are positive emotions in crises? A prospective study of resilience and emotions following the terrorist attacks on the United States on September 11th, 2001", Journal of Personality and Social Psychology, vol.84, n², p.365-376.

FREUD S. (1920), Au-delà du principe du plaisir, In Essais de psychanalyse, Paris, Payot (1963).

GIOIA D., CORLEY K., HAMILTON A. (2013), "Seeking Qualitative Rigor in Inductive Research: Notes on the Gioia Methodology", Organizational Research Methods, vol.16, n¹, p.15-31.

GRAEBNER M., MARTIN J., ROUNDY P. (2012), "Qualitative data: cooking without a recipe", Strategic Organization, vol.10, ${ }^{\circ} 3$, p.276-284.

HANUS M. (2009), "Deuil et résilience : différences et articulation”, Frontières, vol. 22, n¹-2, p. 19-21.

HARRIS S., SUTTON R. (1986), "Functions of parting ceremonies in dying organizations", Academy of Management Journal, vol. 29, n¹, p.5-30.

HAYWARD M., FOSTER W., SARASVATHY S., FREDRICKSON S. (2010), "Beyond hubris: How highly confident entrepreneurs rebound to venture again", Journal of Business Venturing, vol. 25, n6, p.569-578.

ISEN A., BARON R. (1991), "Positive affect as a factor in organizational behavior", Research in Organization Behavior, $\mathrm{n}^{\circ}$ 13, p.1-53.

JENKINS A., WIKLUND J., BRUNDIN E. (2014), "Individual responses to firm failure: Appraisals, grief, and the influence of prior failure experience", Journal of Business Venturing, vol.29, n 1 , p. 1733.

JOSSE E. (2014), Le traumatisme psychique chez l'adulte, Bruxelles, De Boeck.

KARAIRMAK Ö. (2010), "Establishing the psychometric qualities of the Connor-Davidson Resilience Scale (CD-RISC) using exploratory and confirmatory factor analysis in a trauma survivor sample", Psychiatry Research, vol.179, $\mathrm{n}^{\circ} 3$, p.350-356.

KHELIL N., SMIDA A., ZOUAOUI M. (2012), "Contribution à la compréhension de l'échec des nouvelles entreprises : exploration qualitative des multiples dimensions du phénomène", Revue de l'Entrepreneuriat, vol. $11, \mathrm{n}^{\circ} 1$, p. 39-72.

KUMAR R. (1997), "The role of affect in negotiations: An integrative overview", Journal of Applied Behavioral Science, vol.33, ${ }^{\circ} 1, \mathrm{p} .84-100$.

LAMOND A., DEPP C., ALLISON M., LANGER R., REICHSTADT J., MOORE D., GOLSHAN S., GANIATS T., JESTE, D. (2008), "Measurement and predictors of resilience among community dwelling older women", Journal of Psychiatric Research, vol.43, n², p.148-154.

LATOUR B. (2005), Reassembling the Social: An Introduction to Actor-Network-Theory, Oxford: Oxford UP.

LONDON M. (1996), "Redeployment and continuous learning in the 21st century: Hard lessons and positive examples from the downsizing era", Academy of Management Executive, vol.10, n 4 , p.67-79. LUTHAR S., CICCHETTI D., BECKER B. (2000), "The construct of resilience: A critical evaluation and guidelines for future work", Child Development, vol.71, n³, p.543-562.

MADDEN T., ROTH M., DILLON W. (2012), "Global Product Quality and Corporate Social Responsibility Perceptions: A Cross-National Study of Halo Effects", Journal of International Marketing, vol.20, $\mathrm{n}^{\circ} 1, \mathrm{p} .42-57$. 
MANZANO G., AYALA J. (2013), "Psychometric properties of Connor-Davidson Resilience Scale in a Spanish sample of entrepreneurs", Psicothema, vol.25, n², p.245-251.

MARKMAN G., BARON R., BALKIN D. (2005), "Are perseverance and self-efficacy costless? Assessing entrepreneurs' regretful thinking”, Journal of Organizational Behavior, vol.26, n¹, p.1-19.

MATHIAS B., WILLIAMS D., SMITH A. (2015), "Entrepreneurial inception: The role of imprinting in entrepreneurial action", Journal of Business Venturing, vol.30, ${ }^{\circ} 1$, p.11-28.

MAUSS M. (1954), The Gift: Forms and Functions of Exchange in Archaic Societies, Translated by I. Cunnison. Glencoe: The Free Press.

MCGRATH R. (1999), "Falling forward: Real options reasoning and entrepreneurial failure", Academy of Management Review, vol.24, $\mathrm{n}^{\circ} 1, \mathrm{p} .13-30$.

MCKEEVER E., JACK S., ANDERSON A. (2015), "Embedded entrepreneurship in the creative reconstruction of place", Journal of Business Venturing, vol.30, $\mathrm{n}^{\circ} 1, \mathrm{p} .50-65$.

MILLER D., ROSS M. (1975), "Self-serving Biases in the Attribution of Causality", Psychological Bulletin, vol.82, $\mathrm{n}^{\circ} 2, \mathrm{p} .213-225$.

MOHAUPT S. (2009), "Review Article: Resilience and Social Exclusion", Social Policy and Society, vol.8, n $1, \mathrm{p} .63-71$.

MONIN P., RÜLING C.-C. (2013), "Réflexions sur la méthodologie 'à la Gioia"”, XXIIème conférence AIMS, Clermont-Ferrand, 10-12 juin.

NEWMAN R. (2005), “APA's resilience initiative”, Professional Psychology: Research and Practice, vol.36, n³, p.227-229.

PAILOT P. (2014), "Le deuil dans les sciences de l'organisation : Éléments d'analyse critique d'un transfert conceptuel”, Management International, vol.18, $\mathrm{n}^{\circ} 4, \mathrm{p} .12-31$.

REAY T. (2014), "Publishing qualitative research", Family Business Review, vol.27, n², p.95-102.

SHEPHERD D. (2009), "Grief recovery from the loss of a family business: a multi- and meso-level study", Journal of Business Venturing, vol.24, n¹, p.81-97.

SHEPHERD D. (2004), "Educating entrepreneurship students about emotion and learning from failure", Academy of Management Learning and Education, vol.3, n³, p.274-287.

SHEPHERD D. (2003), "Learning from Business Failure: Propositions of Grief Recovery for the SelfEmployed", Academy of Management Review, vol.28, n², p.318-328.

SHEPHERD D., HAYNIE M. (2011), "Venture failure, stigma, and impression management: A selfverification, self-determination view", Strategic Entrepreneurship Journal, vol.5, n², p.178-197.

SHEPHERD D., COVIN J., KURATKO D. (2009), "Project failure from corporate entrepreneurship: managing the grief process", Journal of Business Venturing, vol.24, nº, p.588-600.

SHEPHERD D., WIKLUND J., HAYNIE M. (2009), "Moving forward: Balancing the financial and emotional costs of business failure", Journal of Business Venturing, vol.24, n², p.134-148

SINGH S., CORNER P., PAVLOVICH K. (2015), "Failed, not finished: A narrative approach to understanding venture failure stigmatization”, Journal of Business Venturing, vol.30, n¹, p.150-166.

SINGH S., CORNER P., PAVLOVICH K. (2007), "Coping with entrepreneurial failure", Journal of Management \& Organization, vol.13, n 4 , p.331-344.

SNELL R. (1992), "Experiential learning at work: why can't it be painless?" Personnel Review, vol.21, n 4 , p.12-26.

SUTCLIFF K., VOGUS T. (2003), "Organizing for resilience”, In K. CAMERON, J. DUTTON, R. QUINN (Eds). Positive organizational scholarship (p. 95-110), San Francisco, CA: Berrett-Koehler.

STROEBE M., SCHUT H. (1999), "The dual process model of coping with bereavement", Death Studies, vol.23, n³, p. 197-224.

SUTTON R., CALLAHAN A. (1987), "The stigma of bankruptcy: Spoiled organizational image and its management", Academy of Management Journal, vol.30, n³, p.405-436.

TEDESCHI R., CALHOUN L. (2004), "Post traumatic growth: Conceptual foundations and empirical evidence", Psychological Inquiry, vol.15, ${ }^{\circ} 1, \mathrm{p} .1-18$.

THOMPSON P. (2004), "Pioneering the life story method", International Journal of Social Research Methodology, vol.7, $\mathrm{n}^{\circ} 1, \mathrm{p} .81-84$.

TUCKER A., EDMONDSON A. (2003), "Why Hospitals Don't Learn from Failures: Organizational and Psychological Dynamics that Inhibit System Change", California Management Review, vol. 45, $\mathrm{n}^{\circ} 2, \mathrm{p} .55-72$. 
UCBASARAN D., SHEPHERD D., LOCKETT A., LYON J. (2013), "Life After Business Failure: The Process and Consequences of Business Failure for Entrepreneurs", Journal of Management, vol.39, $\mathrm{n}^{\circ} 1$, p.163-202.

UCBASARAN D., WESTHEAD P., WRIGHT M., FLORES M. (2010), "The nature of entrepreneurial experience, business failure and comparative optimism", Journal of Business Venturing, vol.25, $\mathrm{n}^{\circ} 6$, p.541-555.

WIKLUND J., BAKER T., SHEPHERD D. (2010), "The age effect of financial indicators as buffers against the liabilities of newness", Journal of Business Venturing, vol.25, n 4, p.423-437.

YIN R. (1990). Case Study Research: Design and Methods, Newbury Park, Sage.

ZACHARAKIS A., MEYER G., DECASTRO J. (1999), "Differing perceptions of new venture failure: a matched exploratory study of venture capitalists and entrepreneurs", Journal of Small Business Management, vol.37, $\mathrm{n}^{\circ} 3$, p. 1-14. 
APPENDIX: SUMMARY OF EMPIRICAL DATA

\begin{tabular}{|c|c|c|}
\hline Type of data & Aims/Comments & Quantification \\
\hline \multicolumn{3}{|c|}{ Interviews } \\
\hline $\begin{array}{l}1 \text { exploratory interview with the } \\
\text { President-founder of the } 60.000 \\
\text { Rebonds association }\end{array}$ & $\begin{array}{l}\text { April } 2013 \text { - Insights into the } \\
\text { association }\end{array}$ & $\begin{array}{l}1 \mathrm{H}-\text { Notes } \\
(1 \text { page })\end{array}$ \\
\hline $\begin{array}{l}9 \text { semi-directive focused } \\
\text { interviews ( } 1 \text { President of } 60.000 \\
\text { Rebonds Bordeaux, } 2 \text { coaches, } 3 \\
\text { recovering entrepreneurs, } 2 \\
\text { mentors and } 1 \text { representative of } \\
\text { Crédit Agricole Aquitaine bank). }\end{array}$ & $\begin{array}{l}\text { From February to June } 2014 \text { - } \\
\text { Administration of the interview } \\
\text { guide designed in line with the } \\
\text { research question }\end{array}$ & $\begin{array}{l}\text { 1H37 (on average) - Full } \\
\text { transcription } \\
\text { (194 pages) }\end{array}$ \\
\hline $\begin{array}{l}2 \text { semi-directive focused } \\
\text { interviews with mentors from the } \\
\text { association }\end{array}$ & $\begin{array}{l}\text { January } 2015 \text { - Information about } \\
\text { the role of the mentor in the } \\
\text { association }\end{array}$ & $\begin{array}{l}\text { 1H17 (on average) - } \\
\text { Full transcription } \\
\text { ( } 37 \text { pages) }\end{array}$ \\
\hline $\begin{array}{l}2 \text { semi-directive focused } \\
\text { interviews with associative } \\
\text { partners of } 60.000 \text { Rebonds }\end{array}$ & $\begin{array}{l}\text { January } 2015 \text { - Information about } \\
\text { two important partners of the } \\
\text { association }\end{array}$ & $\begin{array}{l}\text { 1H07 (on average) } \\
\text { Full transcription } \\
\text { ( } 25 \text { pages) }\end{array}$ \\
\hline $\begin{array}{l}1 \text { group validation interview with } \\
3 \text { key figures from the association }\end{array}$ & $\begin{array}{l}\text { March } 2015 \text { - Feedback with } \\
\text { respect to the empirical analyses } \\
\text { and updates to the association data }\end{array}$ & $\begin{array}{l}\text { 1H15 } \\
\text { Partial transcription } \\
\text { (4 pages) }\end{array}$ \\
\hline \multicolumn{3}{|c|}{ Observation } \\
\hline 2 steering committee meetings & $\begin{array}{l}\text { March and April } 2014 \text { - Analysis } \\
\text { of interactions between the } \\
\text { entrepreneurs, coaches, mentors, } \\
\text { committee members and external } \\
\text { partners }\end{array}$ & $\begin{array}{l}\text { 2H53 (on average) - Notes } \\
\text { (24 pages) }\end{array}$ \\
\hline $\begin{array}{l}1 \text { Exchange and Development } \\
\text { Group (EDG) }\end{array}$ & $\begin{array}{l}\text { April } 2014 \text { - Analysis of the } \\
\text { association's main collective } \\
\text { support tool }\end{array}$ & $\begin{array}{l}2 \mathrm{H}-\text { Notes } \\
(8 \text { pages })\end{array}$ \\
\hline \multicolumn{3}{|c|}{ Conferences } \\
\hline $\begin{array}{l}1 \text { conference-debate, organised by } \\
\text { the association: 'Recovering after } \\
\text { a failure, a new } \\
\text { entrepreneurial project: account } \\
\text { of one year's experience with } \\
60.000 \text { Rebonds' }\end{array}$ & $\begin{array}{l}\text { July } 2013 \text { (effective participation) } \\
\text { - Insights into the association, its } \\
\text { activities, its processes, etc., with } \\
\text { the narrative accounts of } 3 \\
\text { recovering entrepreneurs }\end{array}$ & $\begin{array}{l}3 \mathrm{H}-\text { Notes } \\
(1 \text { page })\end{array}$ \\
\hline $\begin{array}{l}1 \text { conference 'Tomber et se } \\
\text { relever' (Falling and picking } \\
\text { yourself up) in the framework of } \\
\text { the MEDEF University, with the } \\
\text { participation of the President- } \\
\text { founder of the } 60.000 \text { Rebonds } \\
\text { association }\end{array}$ & $\begin{array}{l}\text { August } 2013 \text { (video) - Experience } \\
\text { of the President-founder with } \\
\text { regards to the association }\end{array}$ & $\begin{array}{l}\text { 1H54 - Notes } \\
\text { (1 page) }\end{array}$ \\
\hline $\begin{array}{l}1 \text { 'Rebondir' (recovery) } \\
\text { conference with the President- } \\
\text { founder of the } 60.000 \text { Rebonds } \\
\text { association }\end{array}$ & $\begin{array}{l}\text { January } 2014 \text { (video) - Experience } \\
\text { of the President-founder with } \\
\text { regards to the association }\end{array}$ & $\begin{array}{l}1 \mathrm{H} 47 \text { - Notes } \\
\text { (6 pages) }\end{array}$ \\
\hline $\begin{array}{l}1 \text { national forum on recovering } \\
\text { after a bankruptcy organised by } \\
\text { the } 60.000 \text { Rebonds association }\end{array}$ & $\begin{array}{l}\text { November } 2014 \text { - Experience of } 4 \\
\text { recovering entrepreneurs, } 2 \\
\text { mentors, } 2 \text { coaches, several } \\
\text { partners, etc. }\end{array}$ & $\begin{array}{l}3 \mathrm{H}-\text { Partial transcription } \\
(16 \text { pages })\end{array}$ \\
\hline \multicolumn{3}{|c|}{ Lived experiences } \\
\hline $\begin{array}{l}2 \text { video accounts of recovering } \\
\text { entrepreneurs' experiences } \\
\text { (association website) }\end{array}$ & $\begin{array}{l}\text { Narratives of recovering } \\
\text { entrepreneurs supported by the } \\
\text { association }\end{array}$ & $\begin{array}{l}18 \text { min. (on average) }- \text { Full } \\
\text { transcription } \\
\text { ( } 7 \text { pages })\end{array}$ \\
\hline $\begin{array}{l}2 \text { written accounts by recovering } \\
\text { entrepreneurs (association } \\
\text { website) }\end{array}$ & $\begin{array}{l}\text { Narratives of recovering } \\
\text { entrepreneurs supported by the } \\
\text { association }\end{array}$ & $\begin{array}{l}\text { Full transcription } \\
\text { ( } 2 \text { pages })\end{array}$ \\
\hline
\end{tabular}




\begin{tabular}{|c|c|c|}
\hline \multicolumn{3}{|c|}{ Media } \\
\hline $\begin{array}{l}1 \mathrm{TV} \text { report (France 2) 'Le rebond } \\
\text { des petits patrons' (the recovery of } \\
\text { small business owners) }\end{array}$ & $\begin{array}{l}\text { May } 2014 \text { - Narrative of a } \\
\text { recovering entrepreneur supported } \\
\text { by the association }\end{array}$ & $\begin{array}{l}40 \text { min - Full transcription (13 } \\
\text { pages) }\end{array}$ \\
\hline 32 national and local press articles & $\begin{array}{l}\text { Interviews with the president- } \\
\text { founder, experience of recovering } \\
\text { entrepreneurs and volunteers, } \\
\text { analysis of the association's } \\
\text { activities, etc. }\end{array}$ & $\begin{array}{l}\text { Full transcription } \\
\text { (44 pages) }\end{array}$ \\
\hline \multicolumn{3}{|c|}{ Miscellaneous documents } \\
\hline $\begin{array}{l}\text { Discovery report (PowerPoint } \\
\text { presentation) }\end{array}$ & $\begin{array}{l}\text { Views of the Crédit Agricole } \\
\text { Aquitaine bank on their } \\
\text { partnership with the association }\end{array}$ & $\begin{array}{l}\text { Full document } \\
\text { (39 pages) }\end{array}$ \\
\hline Status of the association & $\begin{array}{l}\text { General information about the } \\
\text { association (constitution, aims, } \\
\text { members, admission conditions, } \\
\text { resources, etc.) }\end{array}$ & $\begin{array}{l}\text { Full document } \\
\text { (5 pages) }\end{array}$ \\
\hline Association charter & $\begin{array}{l}\text { General information about the } \\
\text { association (aims, selection of } \\
\text { entrepreneurs, working methods of } \\
\text { the selection committee, recovery } \\
\text { support plan, stages of the support } \\
\text { programme, values, etc.). }\end{array}$ & $\begin{array}{l}\text { Full document } \\
\text { (4 pages) }\end{array}$ \\
\hline The association processes & $\begin{array}{l}\text { Details of the association's } \\
\text { reception and support processes } \\
\text { (coaching, mentoring, Exchange } \\
\text { and Development Groups, etc.). }\end{array}$ & $\begin{array}{l}\text { Full document } \\
\text { (31 pages) }\end{array}$ \\
\hline Coaching report & $\begin{array}{l}\text { Details of support in the form of } \\
\text { coaching (charter of the approach, } \\
\text { aims and contents, process, } \\
\text { duration and pace, followed by an } \\
\text { action plan, the entrepreneur's } \\
\text { personal diagnosis tools, etc.). }\end{array}$ & $\begin{array}{l}\text { Full document } \\
\text { (31 pages) }\end{array}$ \\
\hline Financial report & $\begin{array}{l}\text { Balance of income and } \\
\text { expenditure of } 2014 .\end{array}$ & $\begin{array}{l}\text { Full document } \\
\text { (3 pages) }\end{array}$ \\
\hline Moral report & $\begin{array}{l}\text { Assessment of the association's } \\
\text { functioning for } 2014 \text {. }\end{array}$ & $\begin{array}{l}\text { Full document } \\
\text { ( } 7 \text { pages) }\end{array}$ \\
\hline Guide & Details of mentoring support & $\begin{array}{l}\text { Full document } \\
\text { (5 pages) }\end{array}$ \\
\hline Satisfaction survey & $\begin{array}{l}\text { Information on the association's } \\
\text { success indicators }\end{array}$ & $\begin{array}{l}\text { Full document } \\
\text { (1 page) }\end{array}$ \\
\hline Organization chart & $\begin{array}{l}\text { Information on the volunteer } \\
\text { members (role, expertise, etc.) }\end{array}$ & $\begin{array}{l}\text { Full document } \\
\text { (1 page) }\end{array}$ \\
\hline The Association's website & $\begin{array}{l}\text { General information on the } \\
\text { association (aims, structure, } \\
\text { organisation, actions, support } \\
\text { methods, partners, news, etc.) }\end{array}$ & $\begin{array}{l}\text { Full access } \\
\text { (16 pages) }\end{array}$ \\
\hline $\begin{array}{l}\text { IPSOS study 'Comment rebondir } \\
\text { après un échec professionnel?' } \\
\text { (How to recover after a } \\
\text { professional failure) }\end{array}$ & $\begin{array}{l}\text { December } 2013 \text { - Figure-backed } \\
\text { data on entrepreneurial recovery in } \\
\text { France }\end{array}$ & $\begin{array}{l}\text { Full document } \\
\text { (11 pages) }\end{array}$ \\
\hline $\begin{array}{l}\text { Charter of national deployment of } \\
\text { conferences on recovery, co- } \\
\text { signed by the president-founder of } \\
\text { the } 60.000 \text { Rebonds association }\end{array}$ & $\begin{array}{l}\text { January } 2014 \text { - Information on the } \\
\text { association's communication } \\
\text { activities }\end{array}$ & $\begin{array}{l}\text { Full document } \\
\text { (6 pages) }\end{array}$ \\
\hline A4 brochure of 60.000 Rebonds & $\begin{array}{l}\text { November } 2014 \text { - General } \\
\text { information on the association } \\
\text { (association aims, use of the word }\end{array}$ & $\begin{array}{l}\text { Full document } \\
\text { (4 pages) }\end{array}$ \\
\hline
\end{tabular}


'failure', citations, key figures, partners, overview, etc.). 